Elsevier required licence: (c) $<2018>$. This manuscript version is made available under the CC-BY-NC-ND 4.0 license http://creativecommons.org/licenses/bync-nd/4.0/ 


\section{Brain derived neurotrophic factor (BDNF), its tyrosine kinase receptor $B$ (TrkB) and nicotine.}

\section{Rita Machaalani, ${ }^{1,2}$ and Hui Chen ${ }^{3}$}

${ }^{1}$ SIDS and Sleep Apnea Laboratory, Sydney Medical School, and ${ }^{2}$ The BOSCH Institute; Medical Foundation Building K25, University of Sydney, NSW 2006, Australia; ${ }^{3}$ School of Life Sciences, Faculty of Science, University of Technology Sydney, Broadway, NSW 2007 Australia

Abbreviated title: BDNF \& TrkB after nicotine exposures

\section{Corresponding Author:}

Dr. Rita Machaalani

SIDS \& Sleep Apnea Laboratory Sydney Medical School- Central

Room G77, Medical Foundation Building, K25

UNIVERSITY OF SYDNEY, 2006, NSW

$\mathrm{T}+61290363482$

E rita.machaalani@sydney.edu.au 


\begin{abstract}
Nicotine is the major neurotoxicant in cigarettes that affects many transmitter systems within the brain as well as other factors, including the growth factors. Brain derived neurotrophic factor (BDNF), is the most abundant growth factor in the brain and plays a critical role in early new neuron differentiation, development and synapsis growth, and the survival of fully developed neurons and synaptic activity. Over the past 3 decades, data has emerged on the effects of nicotine and cigarette smoke exposure on the expression of BDNF and its primary specific receptor tyrosine kinase receptor $\mathrm{B}(\mathrm{TrkB})$. This review summarizes data regarding the changes in brain BDNF expression after nicotine or cigarette smoke exposure, and discusses their implications considering BDNF's functional roles.
\end{abstract}

Keywords: animal models, cigarette smoke exposure, nicotine, neurotrophic factor, infant, NTRK2. 


\section{Introduction}

Brain derived neurotrophic factor (BDNF), is the most abundant neurotrophin growth factor in the brain and is important for cellular growth, development, survival and synaptic activity (Webster et al., 2002, reviewed Cunha et al., 2010). These actions are mediated via BDNF binding selectively to its tyrosine kinase receptor B (TrkB) receptor (Fayard et al., 2005).

Cigarette smoke exposure is the leading modifiable health burden in many countries with an estimated 1.1 billion people smoking in 2015 (WHOa). The consequences are not only on the smokers themselves, but also to those around them via passive smoke exposure, responsible for 7 million deaths per year, including 600,000 from second-hand smoking (WHOb). In addition, smoking is particularly detrimental on the developing young brains if exposed during the gestational period where the effects could be long lasting well into adulthood by causing epigenetic changes (reviewed Poon and Leibowitz 2016).

Our laboratory's interest is on Sudden Infant Death Syndrome (SIDS), for which cigarette smoke exposure is currently the leading modifiable risk factor (Mitchell et al., 2012). This is despite health campaigns advising against it (Mitchell et al., 2012). Although many pregnant women aim to cease smoking during pregnancy, the success rate is low during gestation (Filion et al., 2011). In addition, the relapse rate is high particularly in the early post-natal period. A main hypothesis in SIDS is that it is a developmental disorder of the cardio-respiratory centres in the brainstem (Hunt 1992) and as such, death ensues during a sleep period of either or both a cardiac or respiratory compromising event. BDNF knockout mice show severe depression of respiratory frequency and minute ventilation, with a loss of the hypoxic ventilatory drive, and they die within the first two weeks of life (Balkowiec and Katz, 1998, Erickson et al., 1996, Ernfors et al., 1994). This made it a candidate marker for study in our laboratory within the context of SIDS (Tang et al., 2012).

Nicotine, a main neuroactive component of cigarettes (tobacco), has been shown to directly induce changes in BDNF levels (Summarised in Table 2). In living humans, changes in BDNF are measured via serum or plasma given there is not yet a means to sensitively and accurately visualise and measure BDNF levels in the brain using imaging systems (Fukuchi et al., 2017). Despite this, evidence exists that peripheral (serum and plasma) BDNF levels do correlate with brain BDNF levels (Karege et al., 2002, Klein et al., 2011) and as such, can be used as surrogates of brain changes. That said, verification is advantageous and to this end, animal studies provide such assurance. Over the past three decades, many animal models of cigarette smoke and/or nicotine exposure have been developed and studied in relation to the effects on BDNF and TrkB expression 
in the brain. This review will summarise these studies and aim to provide a mechanistic explanation for the changes observed.

\section{The BDNF System}

Growth factors are required for the normal development and functioning of the central nervous system. One family of growth factors is the neurotrophin family, which consists of nerve growth factor (NGF), BDNF, neurotrophin-3 (NT-3), and neurotrophin-4/5 (NT-4/5). Neurotrophins are known for their roles during development and maintenance of the nervous system and have been detected as early as during embryonic development (reviewed in Bernd, 2008).

All neurotrophins are synthesised as pre-pro-neurotrophin precursors (approximately 240-260 amino acids long) within the rough endoplasmic reticulum and undergo several processes to convert into pro-neurotrophins and neurotrophins (Edwards et al., 1988; Seidah et al., 1996). Once formed they then accumulate in the membrane stacks of the trans-Golgi network and are secreted via two different types of secretory vesicles (constitutive or regulated) available for intracellular protein trafficking. The secretory vesicles are characterised according to their mechanism of secretion. The constitutive secretory vesicles release the neurotrophins in the absence of any specific triggering mechanism, whereas the regulated secretory vesicles release neurotrophins in an activity-dependent manner or in response to the stimuli, such as stress and hypoxia (reviewed by Cunha et al., 2010). Pro-neurotrophins not only promote the synthesis of neurotrophins, but can also act as ligands, with both often having opposing effects.

\section{BDNF Production}

As a neurotrophin, BDNF consists of two forms, pro and mature. Throughout the literature, the terms mature-BDNF, rh-BDNF, and BDNF are used interchangeably, but refer to the same form. Therefore in this review, the term BDNF will be used when referring to these. The pro- and matureforms differ in function, primarily due to the neurotrophin receptors they activate. BDNF is generated from proBDNF by cleaving to extracellular proteinase plasmin (Pang et al., 2004) and undergoes $\mathrm{N}$-terminal cleavage within the trans-Golgi network and/or immature secretory vesicles (Mowla et al., 2001). The intracellular conversion of proBDNF to BDNF is predominantly mediated by prohormone convertase (Seidah et al., 1996, Ullal et al., 2007). ProBDNF and BDNF play opposing roles by binding to two structurally unrelated receptors, the p75 neurotrophin receptor (p75NTR) and the TrkB, respectively (Chao, 2003; Patapoutian and Reichardt, 2001). ProBDNF through the activation of p75NTR facilitates apoptosis (Teng et al., 2005), whereas 
BDNF through the activation of the TrkB receptor, promotes neuronal survival and axonal growth (Rose et al., 2004).

Once formed, BDNF is stored in the nerve terminals (Luo et al., 2001) and secreted through the regulated secretory pathway in an activity-dependent manner. Activity-dependent release of BDNF may be triggered by direct activation of voltage-gated $\mathrm{Na} 2+$ channels, which requires both $\mathrm{Ca} 2+$ influx and mobilization of $\mathrm{Ca} 2+$ from intracellular stores (Balkowiec and Katz, 2002). BDNF is transported both retrogradely and anterogradely (Ernfors et al., 1994, Tonra, 1999, Zhou and Rush, 1996). Anterograde transport is performed by sensory neurons towards both peripheral and central targets (Zhou and Rush, 1996), whereas the retrograde transport is used for target derived neurotrophic support (Tonra, 1999).

\section{TrkB Receptor}

The cellular actions of BDNF are mediated through the activation of its receptors. ProBDNF and BDNF bind selectively to TrkB and to p75NTR. BDNF binds to TrkB with high affinity and to p75NTR with low affinity, whereas proBDNF binds primarily to p75NTR and secondarily to TrkB, but not to TrkA or TrkC (Fayard et al., 2005). Given this review is focused on BDNF alone, the remainder of this section will only address TrkB.

The activation of TrkB receptors is a two-step process; ligand-mediated oligomerization of receptor molecules at the cell surface, followed by autophosphorylation of their tyrosine residues in the cytoplasmic domain (Schlessinger and Ullrich, 1992, reviewed in Cunha et al., 2010). Autophosphorylation promotes recruitment of a series of intracellular proteins and triggers signal transduction pathways (Patapoutian and Reichardt, 2001). After BDNF binds to TrkB at the cell surface, Na+ channels open. Once this has taken place, phosphorylation of Trk kinase activates phospholipase C- $\gamma$ (PLC- $\gamma)$, resulting in,

1- The formation of the second-messengers diacylglycerol and inositol 1,4,5 triphosphate (IP3) (Rose et al., 2004). IP3 induces the release of Ca2+ stores, increasing intracellular levels of $\mathrm{Ca} 2+$ thereby activating several pathways that are controlled by $\mathrm{Ca} 2+$ (Patapoutian and Reichardt, 2001), and;

2- The opening of transient receptor potential ion 3 channels (TRPC3) which are located adjacent to the $\mathrm{TrkB}$ receptors, and causes an influx of $\mathrm{Na}+$ and $\mathrm{Ca} 2+$ leading to the modulation of synaptic transmission (Rose et al., 2004, reviewed in Cunha et al., 2010, schematically provided Figure 1). 
The deletion of TrkB via knockout technology reduces presynaptic and postsynaptic development, and electrophysiological responses. These effects indicate that TrkB has a role in excitatory synaptic formation (Luikart et al., 2005). TrkB knockout mice died within 24 to 48 hours of birth and this was attributed to their failure to feed due to abnormalities (predominantly increased apoptotic cell death (Alcañtara et al. 1997, Holm et al. 2003)) in the motor neural system involved in swallowing (Klein et al., 1993). This indicates the critical role of TrkB in survival and brain apoptotic regulation. Moreover, differential regulation of $\operatorname{TrkB}$ has been found in many neuropathological conditions across various age spectrums with downregulation generally observed in neuro-psychiatric, -degenerative and -dependent disorders, while upregulation is seen in tumour related disorders and tissue injury (reviewed Gupta et al., 2013).

\section{Physiological functions of BDNF}

BDNF is involved in the promotion of normal nervous system development, through promoting neurite growth and establishing synaptic connections between neurons and target cells (CohenCory, 2002), and via the interaction with other major neurotransmitter systems including glutamatergic, gabaergic, serotoninergic and dopaminergic (reviewed Changeux 2012, Autry and Montegia 2012). During development, high levels of BDNF expression are required for the normal development of the nervous system (Webster et al., 2002). Once the nervous system is developed, maintenance and stabilisation is promoted through the process of long-term potentiation (LTP). LTP is defined as "a stable, relatively long lasting increase in the magnitude of a post-synaptic response to a constant afferent volley following brief tetanic stimulation of the same afferents" (Teyler and DiScenna, 1987). Thus, it is where synaptic activity between brain cells occurs, leading to the formation of plasticity and memory (Ernfors and Bramham, 2003). BDNF has been shown to be important in promoting LTP (Korte et al., 1996) and the presence of BDNF can significantly improve LTP deficits in basal synaptic transmission in BDNF null mice (Patterson et al., 1996). The effects of BDNF on LTP are mediated by cAMP-response-element-binding protein (CREB) that regulates the expression of genes involved in the function of LTP (Ernfors and Bramham, 2003).

Physiologically, identified through BDNF knockout (KO) mice models, BDNF is important for the regulation of:

1- Respiration: BDNF KO mice showed severe depression of respiratory frequency and minute ventilation, with a loss of the hypoxic ventilatory drive (Balkowiec and Katz 1998, Erickson et al., 1996); 
2- Coordination of movement and balance: BDNF KO mice had poor motor coordination and body balance (Conover et al., 1995);

3- Survival during early postnatal period: BDNF KO mice failed to thrive beyond postnatal day 8 (Conover et al., 1995, Ernfors et al., 1994, Jones et al., 1994).

These functions were affected predominantly as a result of increased neuronal apoptosis (Bianchi et al. 1996, Ernfors et al., 1994, Patel and Krimm 2010), decreased differentiation (Jones et al., 1995), and deficits in synaptic function/ synaptogenesis (Korte et al., 1996, Patterson et al., 1996), particularly in the thalamus (Lotto et al. 2001), substantia nigra (Baker et al. 2005), cerebellum (Schwartz et al. 1997) and sensory ganglia that innervate the inner ear and vestibular system (Bianchi et al. 1996, Ernfors et al., 1994). The death of the BDNF KO mice during the early postnatal period is believed to be due to the increased death of sensory neurons in the petrosal and nodose ganglia (Jones et al., 1994), given they relay information from the heart, lungs, great blood vessels, and gut to the central nervous system.

The expression and modulation of BDNF are regulated by various insults including stress, hypoxia, ischemia, seizure activity, temperature change, hypoglycaemia, and exposures to neurotoxic drugs (Reviewed in Tapia-Arancibia et al., 2004). Such changes in BNDF expression are also responsible for neurological conditions, such as anxiety, depression, epilepsy, Alzheimer's and Parkinson's disease. Indeed, abnormal immunostaining results of both BDNF and TrkB have been reported in the hippocampus of patients with schizophrenia (Iritani et al., 2003). This review will focus on the changes of BDNF and TrkB expression induced by nicotine exposure.

\section{Nicotine and nicotinic acetylcholine receptors (nAChRs)}

Nicotine is the major addictive and neurotoxic agent of cigarettes/tobacco (Dani and Heinemann 1996, Benowitz 1996), and unlike many of the compounds present in tobacco smoke, has no major environmental sources other than tobacco. Nicotine dependence is more prevalent than dependence on any other substance of abuse (Markou 2008), especially when tobacco is legal to consume and sell compared with the other substances. Nicotine's predominant effects are induced by activating the nAChRs. The nAChRs belong to the cys-loop family of ligand-gated ion channels that exist as pentamers of subunits, arranged symmetrically around a central pore (Cooper et al., 1991). A total of seventeen subunits $(\alpha 1-10, \beta 1-4, \varepsilon, \gamma$ and $\delta)$ have been identified, and all subunits are of mammalian origin with the exception of $\alpha 8$ which is avian (Papke et al., 2008). nAChRs are found at skeletal neuromuscular junctions and autonomic ganglia as either homopentamers or heteropentamers. Within the central nervous system, the predominant conformation of these 
subunits is heteromeric, although $\alpha 7$ and $\alpha 9$ homopentamers exist. The $\alpha 7$ homomeric and $\alpha 4 \beta 2$ heteromeric nAChRs are the two main types widely expressed throughout the whole brain with the $\alpha 7 \mathrm{nAChRs}$ characterized by a fast activation, low affinity and high $\mathrm{Ca}^{2+}$ permeability while the $\alpha 4 \beta 2$ are characterised by a high affinity and slow desensitization. The expression of other nAChR subunits are more restricted within the brain (Reviewed Gotti and Clementi 2004).

Normal synaptic activity in the brain relies on the nAChRs via their response to endogenous acetylcholine (ACh), and have been implicated in physiological functions such as sleep, fatigue, anxiety, the central processing of pain, food intake and a number of cognitive functions (Role and Berg, 1996, Gotti et al., 1997, Lindstrom, 1997). However, abnormal (either excessive or deficient) ACh innervation of the nAChRs can lead to various diseases throughout the life span including frontal lobe epilepsy (Steinlein, 2000), schizophrenia (Freedman et al., 2000) and Alzheimer's disease (Wang et al., 2000).

The activation of brain nAChRs by nicotine also results in abnormal synaptic activity and changed neuropathology (reviewed in Slotkin, 1998), including addiction, increased apoptosis (cell death) (Trauth et al., 2000, Machaalani and Waters, 2005), and abnormal expressions of neurotransmitters and their receptors such as glutamate (Fanous et al., 2006), serotonin (Say et al., 2007), orexin (reviewed by Machaalani et al., 2016), and dopamine (Slotkin, 1998). The latter is thought to be associated with increased endorphin levels and increased addiction to nicotine. Moreover, a direct change in the expression (Browne et al., 2010, Vivekanandarajah et al., 2015, Vivekanandarajah et al., 2016) and functions (Sparks and Pauly, 1999, Buisson and Bertrand, 2001) of the nAChRs occur in response to nicotine exposures.

\section{Human studies of nicotine on BDNF and TrkB}

The majority of the human studies of nicotine's effects on BDNF involve DNA genotyping for BDNF SNP variants. Such studies where adult smokers were genotyped found several associations between allelic variations of BDNF and nicotine dependence, yet some variations were evident according to sex and ethnicity (Beuten et al., 2005, Lang et al., 2007, Zhang et al., 2012, 2015, 2016). Two other studies extended the analysis into the offspring of smoking mothers and found the associations between BDNF SNP variants and addiction were indeed present in adolescents (Toledo-Rodriguez et al. 2010, Lotfipour et al., 2009). Such adolescent offspring had a 1.5-fold increase in substance abuse (Lotfipour et al., 2009). Only one study has looked at the effects of nicotine exposure on TrkB in humans and this study was also a genotype study of 9 SNPs within 
the TrkB gene (NTRK2). An association between the allelic variants of NTRK2 and three nicotine dependence measures were found in European-American smokers (Beuten et al., 2007).

Given the limitations in directly studying brain BDNF in living humans, BDNF levels have primarily been studied in the periphery, via serum or plasma. Peripheral BDNF is highly concentrated in the platelets (Fujimura et al., 2002), with serum having approximately 50-200-fold higher levels than the plasma (Radka et al., 1996, Rosenfeld et al., 1995). This difference is suggested to reflect the release of BDNF from platelets during blood clotting (Fujimura et al., 2002). This could also explain why BDNF levels were found to vary according to diurnal rhythm in plasma but not in serum (Piccinni et al., 2008), and to decrease with aging or weight gain in plasma but not in platelets or serum (Lommatzsch et al., 2005). Regarding brain levels, derived from animal studies, peripheral and brain BDNF levels do correlate, yet this was species dependent; yes in the rat and pig, but no in the mouse (Karege et al., 2002, Klein et al., 2011). However, Klein et al., 2011 suggest that the lack of any trace of BDNF in mouse blood may not be a true finding, but rather due to the low sensitivity of the commercially available ELISA kit. This is based on the finding that mice readily transport iodine-labelled BDNF and recombinant BDNF in the blood (Pan et al. 1998). Nevertheless, based on the strong evidence from the studies in the rat and pig, it can be extrapolated that peripheral (serum and plasma) measures of BDNF in the human would be representative of brain levels.

To date, six studies have been conducted in humans to determine the effects of nicotine (via cigarette smoking) on peripheral BDNF levels (summarised in Table 1). From these studies, the predominant direction of change due to nicotine exposure is increased BDNF (Zhang et al., 2010, Suriyaprom et al., 2013, Jamal et al., 2015, Neves et al., 2017). The initial two studies performed by Kim et al. and Bhang et al. were performed on plasma with relatively small sample size and showed that healthy adult smokers had decreased plasma BDNF than the non-smokers; when smoking was ceased for > 4 weeks, BDNF levels increased to the non-smoker's levels or above (Kim et al., 2007, Bhang et al., 2010). The subsequent studies performed on serum with larger sample size showed that both schizophrenic (Zhang et al., 2010) and healthy adults (Suriyaprom et al., 2013, Jamal et al., 2015, Neves et al., 2017) had increased serum BDNF levels and this was associated /correlated with the amount and duration of cigarette smoking and blood cortisol levels, but not with the BDNF Val66Met genotype (Suriyaprom et al., 2013). Combined, these studies provide strong evidence that nicotine exposure in humans affects BDNF expression and this is most likely to be a consequence of the changes in brain BDNF levels, something that animal studies have helped to clarify as discussed in the next section. 
Our laboratory was the first to report BDNF and TrkB expression in the human infant brain (brainstem and hippocampus) (Tang et al., 2010) and subsequently to report the effects of cigarette smoke exposure amongst these infants, for whom the predominating diagnosis was Sudden Infant Death Syndrome (SIDS) (Tang et al., 2011). We found that infants for whom, at the time of death, the parents had indicated a positive history of cigarette smoke exposure (be it the mother, father, both or any other household member), no change in BDNF expression was observed in the brainstem nuclei studied, yet an increase in proBDNF and decrease in TrkB was evident in the hypoglossal and vestibular nuclei, both having a role in respiratory control (Tang et al., 2011). A subsequent study from another laboratory showed that in the kolliker-fuse nucleus (also important for respiratory control), altered BDNF expression was evident amongst infants with cigarette smoke exposure (Lavezzi et al., 2014) and this was extended into the cerebellum showing decreased BDNF levels in both brain regions (Lavezzi et al., 2018). Combined, these studies provide the first reports that exposure of the developing human to pre- and/or postnatal cigarette smoke alters BDNF and TrkB expression in respiratory regulating regions and could have played a role in subsequent pathophysiology changes leading to death.

\section{Animal models of nicotine and cigarette smoke exposure}

Given the limitations of studying brain BDNF in humans, animal studies are developed to provide the much needed data. With regards to nicotine exposure, to ensure the animals are receiving doses that equate to human consumption, measures of either nicotine or cotinine levels in the blood or urine are performed, with measurement of cotinine preferred given its longer half life (16 hours versus 2 hours for nicotine)(Benowitz and Jacob, 1993). The metabolism, distribution and excretion rate of nicotine differs with species, hence slight variations would be anticipated (Bramer and Kallungal 2003). To mimic childhood and adult cigarette smoke exposure paradigms, doses should be approximately $6 \mathrm{mg} / \mathrm{kg} /$ day to produce cotinine levels indicative of active smoking which is $>220 \mathrm{ng} / \mathrm{ml}$ or $100 \mathrm{nmol} / \mathrm{L}$ in serum and $>3516 \mathrm{ng} / \mathrm{ml}$ or $1,700 \mathrm{nmol} / \mathrm{L}$ in urine (Vine et al., 1993, SSWPS Handbook 2014). For early postnatal exposure, as would be experienced by babies through breast milk or environmental passive smoke exposure, the dose should be within $2-4 \mathrm{mg} / \mathrm{kg} / \mathrm{day}$ resulting in plasma and urine cotinine levels $>5 \mathrm{ng} / \mathrm{ml}$ and $>10 \mathrm{ng} / \mathrm{ml}$ respectively (Luck and Nau, 1985). For maternal (prenatal) cigarette smoke exposure, doses should be within $2-6 \mathrm{mg} / \mathrm{kg} / \mathrm{day}$, resulting in plasma cotinine levels of $>100 \mathrm{ng} / \mathrm{ml}$ (Murrin et al., 1987, Lichtensteiger et al., 1988).

The mode of administration is another consideration when developing the animal model of nicotine exposure. The common methods to date include: gavage, injection (intraperitoneal or 
subcutaneous), infusion, osmotic minipump infusion, dermal patches or placing the animal in a cigarette smoke exposure chamber. Current studies lean towards the use of minipumps and nicotine patches given they result in steady states of plasma nicotine levels and overcome the hypoxiaischemia effects which were seen to occur when using the injection method (Slotkin 1998). A recent review addressing the various animal models of nicotine exposure and their results is provided by Cohen and George 2013.

\section{Nicotine exposure on BDNF expression in the brain from animal studies (Table 2).}

The baseline expression of BDNF has been extensively studied amongst species including the rat pup, (Hafidi et al., 1999), piglet (Pieris et al., 2004, Tang et al., 2008), gerbil (Tierney et al., 2001), adult rat (Hafidi et al., 1999, Kawamoto et al., 1996, Yan et al., 1997), adult monkey (Kawamoto et al., 1999, Zhang et al., 2007), human infant (Tang et al., 2010, Tang et al., 2011), and human adult (Murer et al., 1999, Tang et al., 2010).

To date, a modest number of studies have examined the effects of nicotine or cigarette smoke exposure, both prenatally and postnatally, on the expression of BDNF within the brain (summarized Table 2). Majority of the studies in Table 2 were conducted in the rat and mouse with the exception of our own study in piglets (Tang et al., 2008). Moreover, the majority focused on the male sex and adult age. It is only recently (since 2011) that studies have commenced to look at the effects of prenatal nicotine exposure on BDNF expression in the offspring (Table 2). The expression of BDNF was measured at both mRNA and protein levels, and were via real-time polymerase chain reaction (RT-PCR), in situ hybridisation (ISH), western blotting (WB), immunohistochemistry (IHC), and enzyme-linked immunosorbent assays (ELISAs). The main brain regions studied included the hippocampus, prefrontal cortex (PFC), and dorsal striatum (dSTR), with a few studies on the nucleus accumbens (NAc) within the basal forebrain, and our own being the only one on the brainstem (Tang et al., 2008). The rationale for the study of these brain regions relates to the addictive nature of nicotine and interplay with the dopaminergic, glutamatergic and Gabaergic systems (PFC, dSTR and NAc) (Reviewed Feduccia et al., 2012), and the role of nicotine in affecting LTP (hippocampus) and respiratory control (brainstem).

As shown in Table 2, the paradigms of nicotine exposure vary considerably including the age, dose, duration, and method of exposure. All these not surprisingly, lead to differing outcomes. In general, there is a consensus that BDNF expression increases after pre- and post-natal nicotine exposures in the NAc (Table 3), yet for the hippocampus, PFC and dSTR, an increase, decrease or no change in BDNF expression can occur (Table 3). Another contributing factor for the differences could be the 
heterogeneous cell constituents and regions within each of these structures if they were studied on their own as shown by IHC and ISH, where specific subregional changes could be identified.

\section{The effect of nicotine exposure on TrkB expression (Table 4)}

The TrkB receptors have also been localised both pre- and post-synaptically, along axons, in synaptic terminals, and in the plasma membrane of dendritic spines and glial cells (Frisen et al., 1993). The localization of TrkB in the synaptic terminal is consistent with the role of TrkB as a mediator of retrograde transport of BDNF to neuronal cell bodies (Murer et al., 2001).

Much less has been reported regarding the effects of nicotine exposure on TrkB expression, with only 5 studies to date (summarised Table 4). All are in the adult brain (French et al., 1999, Sun et al., 2007, Formaggio et al., 2010, Xiao et al., 2015) with the exception of ours in the infant brains (Tang et al., 2008). The general finding seems to be increased TrkB expression in the hippocampus, cortex, and striatum (Table 3), but decreased levels in certain brainstem nuclei, the nucleus accumbens and the ventral tegmental area (Table 4).

\section{Mechanism(s) involved in nicotine induced BDNF and TrkB changes}

The expression of BDNF and TrkB are closely associated with nAChRs, however to date no studies have examined their colocalization. Evidence showing BDNF affecting nAChRs and vice versa predominantly relates to the $\alpha 7 \mathrm{nAChRs}$. The injection of BDNF into cultured embryonic hippocampal (Massey et al., 2006) and adult cervical ganglionic neurons (Zhou et al., 2004) increased $\alpha 7 \mathrm{nAChR}$ expression, and increased the frequency of spontaneous synaptic currents within minutes (Zhou et al., 2004). Blocking $\alpha 7$ nAChRs leads to reduced BDNF mRNA expression in the hippocampus (Freedman et al., 1993). In contrast, exposing $\beta 2$ nAChR knockout mice to nicotine had no effect on brain BDNF levels (Harrist et al., 2004). This suggests that the $\alpha 4$ component of the $\alpha 4 \beta 2 \mathrm{nAChRs}$ is the predominating component interacting with BNDF after nicotine exposure. This is somewhat in line with the finding that almost all reported human studies of nicotine dependence found no association of the gene for the nAChR $\beta 2$ subunit (CHRNB2) with nicotine dependence ( $\mathrm{Li}$ et al., 2005, Feng et al., 2004, Silverman et al., 2000, Lueders et al., 2002) but did so for the a4 subunit gene (CHRNA4) (Li et al., 2005, Feng et al., 2004, Hutchison et al., 2007). Subsequent analysis showed a strong interaction of CHRNA4 with BDNF and CHRNB2 with TrkB (Li et al., 2008).

Non-homology in BDNF and nAChRs expression changes have also been reported. In our laboratory using the infant piglet model of nicotine exposure, no change in BDNF protein 
expression was observed in any of the brainstem nuclei studied (Tang et al., 2008) despite there being expression changes in $\alpha 2, \alpha 3, \alpha 4, \alpha 7, \alpha 9$, and $\beta 2$ nAChR subunits (Vivekanandarajah et al., 2015). The converse was reported by Romano et al. where they found nicotine exposure increased BDNF mRNA in the hippocampus and cortex, but had no effect on the nAChR subunits $\alpha 2, \alpha 4, \alpha 7$, and $\beta 2$ (Romano et al., 2014). Thus, it remains in question whether the changes in BDNF expression after nicotine exposure are entirely dependent on $\mathrm{nAChR}$ activation and if so, via which subunits and to what level of activation.

Based on the data and knowledge to date, we propose two mechanisms involved in nicotine induced changes of BDNF and TrkB (Figure 1). In the presence of nicotine, the nAChRs are activated, with the specific subunits dependent on the brain region. Upon binding, there is an influx of $\mathrm{Ca} 2+$ which causes an increased BDNF release with the precise mechanism still unknown, yet excitatory pathways via the n-methyl-d-aspartate receptor are implicated (Obrietan et al., 2002). This increases BDNF binding to TrKB, which leads to toxic levels of $\mathrm{Ca} 2+$ which then affects subsequent cascades that regulate cell survival and synaptic activity. Yet, nAChR desensitisation can occur with chronic nicotine exposures, thus reducing the activity of this pathway causing the opposite actions. A nAChR independent pathway is also feasible where nicotine causes direct epigenetic modifications to the BDNF gene which then affects the production of BDNF at both the mRNA and protein levels, thus decreasing the amount of BDNF release. For both mechanisms, a decrease in BDNF expression could be indicative of decreased neuroprotection to subsequent insults, or could be due to increased cell death. Increased BDNF expression could be indicative of increased neuroprotective mechanisms to counteract the 'threat'. Increased TrkB expression seen in most paradigms of nicotine exposure would be indicative of an adaptation to balance BDNF changes to maintain normal homeostasis of cell survival and synaptic activity.

\section{Concluding remarks}

From this review, the majority of the paradigms involving nicotine exposure result in either increased or decreased BDNF expression, and mostly increased or no change in TrkB receptor expression (Summarised in Table 3). However, the majority of studies were undertaken in the adult rat and predominantly in the hippocampus and prefrontal cortex. Thus, further studies are required to determine the changes at other developmental stages, such as prenatal and early postnatal periods, and across other brain regions, particularly in regions of respiratory control and coordination of balance and movement as BDNF affects these specific motor controls. A better understanding of BDNF and TrkB change in such brain regions could be of clinical significance, given the long lasting effects of pre-natal nicotine exposure on addictive behaviour in the offspring 
in adulthood (Kendler et al., 2012). This will facilitate breaking the cycle of smoking from the parents to the offspring. 


\section{Figure Legends}

Figure 1. Schematic of (1) BDNF activation of TrkB and the regulation of this process by (2) nicotine. (1) BDNF binds to TrkB which activates and causes adjacently located TRPC 3 channels to allow the influx of $\mathrm{Na}+$ and $\mathrm{Ca} 2+$, as well as opens the sodium and calcium channels to allow the entry of these ions. The entry of Na+ causes the phosphorylation of TrkB which activates PLC $\gamma$ which then activates IP3 leading to increased intracellular $\mathrm{Ca} 2+$ levels. (2) In the presence of nicotine, the nAChRs are activated, with the specific subunits dependent on the brain region. On binding, there is an influx of $\mathrm{Ca} 2+$ which causes increased BDNF release. This has positive feedback on pathway 1 leading to toxic levels of $\mathrm{Ca} 2+$ which then affects subsequent cascades regulating cell survival and synaptic activity. $\mathrm{nAChR}$ desensitisation can also occur, thus reducing this pathway causing opposite effects. A nAChR independent pathway is also feasible via epigenetic modification of the BDNF gene to affect the production of BDNF and pathway 1. 
Table 1- Human studies of nicotine exposure on BDNF system expression levels.

\begin{tabular}{|c|c|c|c|c|}
\hline $\begin{array}{l}\text { Exposure regime } \\
\text { Age \& sex }\end{array}$ & $\mathbf{N}$ values & $\begin{array}{l}\text { Sample \& } \\
\text { method }\end{array}$ & Findings & Reference \\
\hline $\begin{array}{lr}\text { Adult } & \text { male } \\
\text { smokers (at least } \\
5 \text { cigarettes/day } \\
\text { for } 9 \text { years) } \\
\text { before and after } 2 \\
\text { months } \\
\text { smoking } \\
\text { cessation }\end{array}$ & $\begin{array}{l}20 \text { smokers vs } 20 \\
\text { non-smokers; } \\
12 / 20 \quad \text { ceased } \\
\text { smoking unaided }\end{array}$ & Plasma, ELISA & $\begin{array}{l}\downarrow \quad \text { BDNF in } \\
\text { smokers. } \\
\text { Smoking } \\
\text { cessation for } 2 \\
\text { months, } \uparrow \text { BDNF }\end{array}$ & Kim et al., 2007 \\
\hline $\begin{array}{l}\text { Smokers, and } \\
\text { week } 4 \text { \& } 12 \text { of } \\
\text { smoking } \\
\text { cessation }\end{array}$ & $\begin{array}{l}45 \text { smokers vs } 66 \\
\text { non-smokers; } \\
\text { smokers ceased } \\
\text { via varenciline } \\
(\mathrm{n}=12) \text {, nicotine } \\
\text { patch }(\mathrm{n}=21), \quad \text { } \\
\text { unaided }(\mathrm{n}=12) \text {. } \\
\text { But only } 19 \\
\text { maintained until } \\
\text { week 12. Thus } \\
\mathrm{n}=19 \text { for plasma } \\
\text { levels at week } 4 \\
\text { and } 12 \text {. }\end{array}$ & Plasma, ELISA & $\begin{array}{l}\downarrow \quad \text { BDNF } \\
\text { smokers. } \\
\text { Smoking } \\
\text { cessation } \uparrow \text { in } \\
\text { at } 4 \text { and } 12 \\
\text { weeks, and did } \\
\text { not } \\
\text { according differ } \\
\text { cessation method. }\end{array}$ & Bhang et al., 2010 \\
\hline $\begin{array}{l}\text { Adult male } \\
\text { schizophrenia } \\
\text { smokers }\end{array}$ & $\begin{array}{l}102 \text { smokers vs } \\
37 \text { non-smokers }\end{array}$ & Serum ELISA & $\begin{array}{ll}\uparrow \text { BDNF in } \\
\text { schizophrenic } \\
\text { smokers }\end{array}$ & Zhang et al., 2010 \\
\hline $\begin{array}{l}\text { Adult male and } \\
\text { female smokers } \\
\text { (Ethnicity- Thai) } \\
\text { (10-20 } \\
\text { cigarettes/day for } \\
>14 \text { years) }\end{array}$ & $\begin{array}{l}200 \text { smokers vs } \\
111 \text { non-smokers }\end{array}$ & Serum ELISA & $\begin{array}{lr}\uparrow \text { PDNF } & \text { in } \\
\text { smokers. } & \\
\text { Correlated } & \text { with } \\
\text { number } & \text { of } \\
\text { cigarettes } & \\
\text { smoked. } & \text { No } \\
\text { association } \\
\text { between BDNF } \\
\text { Val66Met } \\
\text { genotype } \\
\text { serum BDNF. }\end{array}$ & $\begin{array}{l}\text { Suriyaprom et al., } \\
2013\end{array}$ \\
\hline $\begin{array}{l}\text { Adult male and } \\
\text { females }\end{array}$ & $\begin{array}{lr}564 & \text { Never } \\
\text { smokers, } & 690 \\
\text { former } & \text { smokers, } \\
\text { current } & \text { smokers } \\
\text { (non-dependent= } \\
528 \quad \text { vs } \\
\text { dependent= }\end{array}$ & Serum, ELISA & $\begin{array}{l}\uparrow B D N F \text { in current } \\
\text { smokers (both } \\
\text { dependent and } \\
\text { non having same } \\
\text { levels) }\end{array}$ & Jamal et al., 2015 \\
\hline $\begin{array}{l}\text { Adult male. } \\
\text { Heavy smokers } \\
20 \text { cigarettes/day, } \\
\text { vs light smokers } \\
10 \text { cigarettes/day }\end{array}$ & $\begin{array}{l}14 \text { smokers (7 } \\
\text { heavy, } 7 \text { light) vs } \\
13 \text { non-smokers }\end{array}$ & Plasma, ELISA & $\begin{array}{l}\uparrow B D N F \text { in heavy } \\
\text { smokers and } \\
\text { associated with } \\
\text { lower cortisol } \\
\text { levels at night }\end{array}$ & Neves et al., 2017 \\
\hline
\end{tabular}




\begin{tabular}{|c|c|c|c|c|}
\hline & & & time. & \\
\hline $\begin{array}{l}\text { Infants died } \\
\text { suddenly within } \\
1^{\text {st }} \text { year of life }\end{array}$ & $\begin{array}{lrr}45 & \text { exposed } & \text { to } \\
\text { cigarette } & \text { smoke } \\
\text { vs } \quad 12 & \text { non- } \\
\text { exposed } & \end{array}$ & $\begin{array}{l}\text { IHC for } \\
\text { proBDNF, mature } \\
\text { BDNF, and TrkB } \\
\text { in brainstem } \\
\text { medulla }\end{array}$ & $\begin{array}{l}\uparrow \text { proBDNF in } \\
\text { exposed, } \\
\text { No-change for } \\
\text { rhBDNF, } \downarrow \text { TrkB }\end{array}$ & Tang et al., 2011 \\
\hline $\begin{array}{l}\text { Infants died } \\
\text { suddenly within } \\
1^{\text {st }} \text { year of life }\end{array}$ & $\begin{array}{l}12 \text { exposed to } \\
\text { cigarette smoke } \\
\text { vs } 4 \text { non-exposed }\end{array}$ & $\begin{array}{l}\text { IHC for mature } \\
\text { BDNF, Kolliker } \\
\text { Fuse nucleus } \\
\text { brainstem }\end{array}$ & $\begin{array}{l}\text { Altered } \\
\text { expression }\end{array}$ & $\begin{array}{l}\text { Lavezzi et al., } \\
2014\end{array}$ \\
\hline $\begin{array}{lr}\text { Fetus and Infants } \\
\text { who died } \\
\text { suddenly }\end{array}$ & $\begin{array}{lrr}3 & \text { exposed } & \text { to } \\
\text { cigarette } & \text { smoke } \\
\text { vs } \quad 29 & \text { non- } \\
\text { exposed } & \end{array}$ & $\begin{array}{l}\text { IHC for mature } \\
\text { BDNF, } \\
\text { cerebellum }\end{array}$ & $\begin{array}{l}\downarrow \quad \text { BDNF } \\
\text { exposed }\end{array}$ & $\begin{array}{l}\text { Lavezzi et al., } \\
2018\end{array}$ \\
\hline
\end{tabular}

IHC, Immunohistochemistry, ND, nicotine dependence 
Table 2 Summary of the effects of cigarette smoke and nicotine exposures on brain BDNF expression in animal models

\begin{tabular}{|c|c|c|c|c|}
\hline Models & $\begin{array}{l}\text { Developmental } \\
\text { Stage when } \\
\text { brain studied }\end{array}$ & $\begin{array}{l}\text { Method \& } \\
\text { region }\end{array}$ & Results & References \\
\hline \multicolumn{5}{|l|}{ Postnatal exposure } \\
\hline $\begin{array}{l}\text { s.c. somotic } \\
\text { minipump } \\
\text { nicotine } 2.3 \mu \mathrm{l} / \mathrm{h} \\
\text { for } 14 \text { days }\end{array}$ & $\begin{array}{l}\text { Aged ( } 22-24 \\
\text { month) male rat }\end{array}$ & $\begin{array}{l}\text { RT-PCR, } \\
\text { Hippocampus, } \\
\text { cortex, striatum }\end{array}$ & $\begin{array}{l}\downarrow \text { non-significant } \\
\text { trend } \\
\text { hippocampus }\end{array}$ & $\begin{array}{l}\text { Monteggia et al., } \\
1994\end{array}$ \\
\hline $\begin{array}{l}\text { Acute local } \\
\text { infusion straight } \\
\text { into } \\
\text { hippocampus }\end{array}$ & Adult male rat & $\begin{array}{l}\text { ISH; } \\
\text { Hippocampus }\end{array}$ & No change & $\begin{array}{l}\text { French et al., } \\
1999\end{array}$ \\
\hline $\begin{array}{l}\text { Acute \& Chronic } \\
\text { exposure } \\
\text { [injection twice } \\
\text { daily, } 7 \text { days] }\end{array}$ & Adult rat & $\begin{array}{l}\text { ISH; } \\
\text { Hippocampus }\end{array}$ & $\begin{array}{l}\text { Acute- } \downarrow \text { mRNA } \\
\text { chronic- } \uparrow \text { mRNA }\end{array}$ & $\begin{array}{l}\text { Kenny et al., } \\
2000\end{array}$ \\
\hline $\begin{array}{l}\text { Chronic } \\
\text { exposure [s.c. } \\
0.4 \mathrm{mg} / \mathrm{kg} \\
\text { injection twice } \\
\text { daily, } 7 \text { days] }\end{array}$ & Adult male rat & $\begin{array}{l}\text { MALDI-TOF-MS, } \\
\text { RT-PCR; } \\
\text { Striatum }\end{array}$ & $\begin{array}{l}\downarrow_{\text {mRNA \& }} \\
\text { protein }\end{array}$ & Yeom et al., 2005 \\
\hline $\begin{array}{l}\text { Chronic } \\
\text { exposure } \\
{[1 \mathrm{mg} / \mathrm{kg}, 2 / \text { day, }} \\
4-6 \text { weeks] }\end{array}$ & Adult rat & $\begin{array}{l}\text { WB; } \\
\text { Hippocampus }\end{array}$ & 个protein of CA1 & Aleisa et al., 2006 \\
\hline $\begin{array}{l}\text { Chronic } \\
\text { exposure } \\
2 \mathrm{mg} / \mathrm{kg} / \text { day } \\
\text { nicotine osmotic } \\
\text { minipump for } 14 \\
\text { days }\end{array}$ & Infant piglet & $\begin{array}{l}\mathrm{IHC} \\
\text { brainstem }\end{array}$ & No change & Tang et al., 2008 \\
\hline $\begin{array}{l}\text { Chronic- Orally } \\
6 \mathrm{mg} / \mathrm{kg} / \text { day } \\
\text { from P1-P7 }\end{array}$ & Infant (P8) mice & $\begin{array}{l}\text { ISH; } \\
\text { Hippocampus }\end{array}$ & $\uparrow m R N A$ & $\begin{array}{l}\text { Son and Winzer- } \\
\text { Serhan } 2009\end{array}$ \\
\hline $\begin{array}{l}0.2 \mathrm{mg} / \mathrm{kg} \text { s.c. } \\
\text { injection } 2 \mathrm{x} / \mathrm{day} \\
\text { for } 5 \text { weeks }\end{array}$ & Adult male rat & $\begin{array}{l}\text { ELISA, } \\
\text { hippocampus \& } \\
\text { cortex }\end{array}$ & $\begin{array}{l}\text { 个protein both } \\
\text { regions }\end{array}$ & $\begin{array}{l}\text { Czubak et al., } \\
2009\end{array}$ \\
\hline $\begin{array}{l}\text { 12cigarettes/ } \\
\text { day } 7 \text { days/week } \\
\text { for } 60 \text { days }\end{array}$ & $\begin{array}{l}\text { Adult ( } 2 \text { month) } \\
\text { male mice }\end{array}$ & $\begin{array}{l}\text { ELISA, } \\
\text { hippocampus }\end{array}$ & $\downarrow$ protein & Tuon et al., 2010 \\
\hline $\begin{array}{l}60-65 \\
\mathrm{mg} / \mathrm{kg} / \text { day oral } \\
\text { (drinking water) } \\
\text { for } 7 \text { weeks }\end{array}$ & $\begin{array}{l}\text { Adult ( } 12 \text { weeks) } \\
\text { male mice }\end{array}$ & $\begin{array}{l}\text { ELISA; } \\
\text { striatum (caudate- } \\
\text { putamen), NAc, } \\
\text { amygdala, VTA, } \\
\text { substantia nigra }\end{array}$ & 个protein NAc & $\begin{array}{l}\text { Kivinummi et al., } \\
2011\end{array}$ \\
\hline $\begin{array}{l}\text { Oral } \\
6 \mathrm{mg} / \mathrm{kg} / \mathrm{day} \\
\text { starting P1 }\end{array}$ & $\begin{array}{l}\text { Neonatal (P5 \& } \\
\text { P8) male \& } \\
\text { female mice }\end{array}$ & $\begin{array}{l}\text { ISH; } \\
\text { Hippocampus }\end{array}$ & $\uparrow \mathrm{mRNA}$ in males & $\begin{array}{l}\text { Damborsky and } \\
\text { Winzer-Serhan } \\
2012\end{array}$ \\
\hline $\begin{array}{l}3 \mathrm{mg} / \mathrm{kg} \text { nicotine } \\
\text { i.p. injections } 6 \\
\text { h before killing }\end{array}$ & Adult male mice & $\begin{array}{l}\text { PCR- several bdnf } \\
\text { transcripts; cortex }\end{array}$ & $\uparrow m R N A$ & $\begin{array}{l}\text { Chase and } \\
\text { Sharma } 2013\end{array}$ \\
\hline
\end{tabular}




\begin{tabular}{|c|c|c|c|c|}
\hline $\begin{array}{l}\text { Chronic low (6.3 } \\
\mathrm{mg} / \mathrm{kg} / \text { day) vs } \\
\text { high (18 } \\
\mathrm{mg} / \mathrm{kg} / \text { day) } \\
\text { nicotine osmotic } \\
\text { minipump }\end{array}$ & $\begin{array}{l}\text { Adolescence (4 } \\
\text { weeks) mice }\end{array}$ & $\begin{array}{l}\text { ELISA; } \\
\text { striatum }\end{array}$ & $\begin{array}{l}\downarrow \text { protein in high } \\
\text { exposure }\end{array}$ & $\begin{array}{l}\text { Ortega et al., } \\
2013\end{array}$ \\
\hline $\begin{array}{l}\text { Oral nicotine } \\
\text { (2h/day for } 6 \\
\text { days } 10 \mathrm{mg} / \mathrm{L} \\
\text { nicotine) during } \\
\text { adolescence } \\
\text { (P37-42) }\end{array}$ & $\begin{array}{l}\text { Adult ( } \mathrm{P} 180) \\
\text { male mice }\end{array}$ & $\begin{array}{l}\text { RT-PCR; } \\
\text { hippocampus \& } \\
\text { cortex }\end{array}$ & $\uparrow \mathrm{mRNA}$ & $\begin{array}{l}\text { Romano et al., } \\
2014\end{array}$ \\
\hline $\begin{array}{l}\text { Inhalation for } 10 \\
\text { days during } \\
\text { Infancy (P2-11) } \\
\text { and teenage } \\
\text { (P21-30) }\end{array}$ & Adult (P60)- mice & $\begin{array}{l}\text { RT-PCR \& WB; } \\
\text { hippocampus \& PFC }\end{array}$ & $\begin{array}{l}\text { Infancy- } \downarrow \text { mRNA } \\
\text { hippocampus } \\
\text { only; } \\
\text { Teen- no change }\end{array}$ & Xiao et al., 2016 \\
\hline $\begin{array}{l}\text { Cigarette } \\
\text { inhalation } \\
\text { 2x1hr/day from } \\
\text { P3-P14 }\end{array}$ & $\begin{array}{l}\text { P15 (infancy), } \\
\text { P35 adolescence) } \\
\text { P65 (adulthood) } \\
\text { mice }\end{array}$ & $\begin{array}{l}\text { Immunoassay; } \\
\text { hippocampus }\end{array}$ & $\begin{array}{l}\text { infancy - } \\
\downarrow \text { protein, } \\
\text { adolescence and } \\
\text { adult- no change }\end{array}$ & $\begin{array}{l}\text { Torres et al., } \\
2015\end{array}$ \\
\hline $\begin{array}{l}\text { Cigarette } \\
\text { inhalation } \\
2 \times 1 \mathrm{hr} / \text { day \& i.p } \\
\text { nicotine 3- } \\
9 \mathrm{mg} / \mathrm{kg} / \text { day } \\
\text { short ( } 4 \text { weeks) } \\
\text { vs long term (12 } \\
\text { weeks) } \\
\text { Prenatal exposure }\end{array}$ & Adult rat & $\begin{array}{l}\text { WB, IHC, cerebral } \\
\text { cortex }\end{array}$ & 个protein & Naha et al., 2017 \\
\hline $\begin{array}{l}\text { GD4 osmotic } \\
\text { minipump } \\
\text { nicotine } \\
3 \mathrm{mg} / \mathrm{kg} / \text { day }\end{array}$ & $\begin{array}{l}\text { Adolescence } \\
\text { (P35) female Rats }\end{array}$ & $\begin{array}{l}\text { RT-PCR \& microarray; } \\
\text { PFC, striatum, NAc, } \\
\text { PVN, and the } \\
\text { amygdala. }\end{array}$ & $\begin{array}{l}\uparrow \text { mRNA NAc \& } \\
\text { striatum, } \downarrow \text { PVN }\end{array}$ & Wei et al., 2011 \\
\hline $\begin{array}{l}0.05 \mathrm{mg} / \mathrm{kg} / \mathrm{i} . \mathrm{v} \text {. } \\
\text { injection } 3 \times / \text { day } \\
\text { from GD } 8-21 \text {. } \\
\text { weened P21 }\end{array}$ & $\begin{array}{l}\text { Adolescence } \\
\text { (P35) male \& } \\
\text { female rats }\end{array}$ & $\begin{array}{l}\text { ELISA; } \\
\text { NAc, dSTR, PFC \& } \\
\text { hippocampus }\end{array}$ & $\begin{array}{l}\uparrow \text { protein all } \\
\text { regions }\end{array}$ & $\begin{array}{l}\text { Harrod et al., } \\
2011\end{array}$ \\
\hline $\begin{array}{l}\text { Cigarette } \\
\text { inhalation } \\
4 \mathrm{hr} / \text { day; } \\
5 \text { days/week } \\
\text { from GD4- } \\
\text { parturition; } \\
\text { offspring } \\
\text { weaned P21 }\end{array}$ & $\begin{array}{l}\text { Adult (4 months) } \\
\text { mice }\end{array}$ & $\begin{array}{l}\text { RT-PCR; WB; } \\
\text { striatum }\end{array}$ & $\begin{array}{l}\downarrow \text { mRNA \& } \\
\text { protein in males } \\
\text { only. No } \\
\text { difference } \\
\text { amongst } \\
\text { females. }\end{array}$ & $\begin{array}{l}\text { Yochum et al., } \\
2014\end{array}$ \\
\hline $\begin{array}{l}\text { Single injection } \\
66 \mu \mathrm{g} / \mathrm{kg} \\
\text { bodyweight for } \\
5 \text { days }\end{array}$ & $\begin{array}{l}\text { Neonate-infancy } \\
\text { male rat pups: } \\
\text { group I P1-5, } \\
\text { group II P5-10, } \\
\text { group III P10-15. }\end{array}$ & $\begin{array}{l}\text { ELISA \& WB; } \\
\text { hippocampus \& } \\
\text { frontal cortex }\end{array}$ & $\begin{array}{l}\downarrow \text { in all groups for } \\
\text { both regions }\end{array}$ & $\begin{array}{l}\text { Xiaoyu et al., } \\
2015\end{array}$ \\
\hline $\begin{array}{l}\text { Inhalation GD10 } \\
\text { for } 10 \text { days }\end{array}$ & Adult (P60)- mice & $\begin{array}{l}\text { RT-PCR \& WB; } \\
\text { hippocampus \& }\end{array}$ & $\begin{array}{l}\downarrow_{\text {mRNA both }} \\
\text { brain regions }\end{array}$ & Xiao et al., 2016 \\
\hline
\end{tabular}




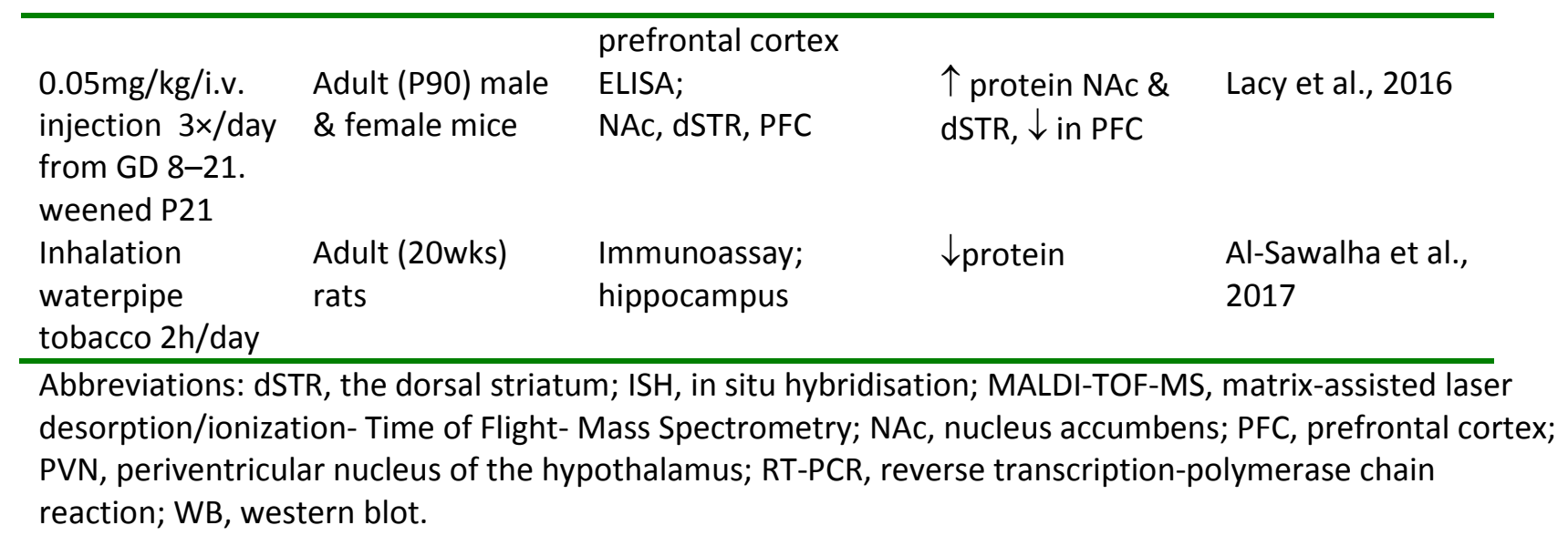


Table 3: The number of studies in Table 2 and 4 that report an increase, decrease or (-) no change in BDNF and TrkB expression in the specific brain region studied.

\begin{tabular}{|c|c|c|c|}
\hline \multirow{3}{*}{$\begin{array}{l}\text { Hippocampus } \\
\end{array}$} & \multicolumn{2}{|c|}{ BDNF } & \multirow{3}{*}{$\begin{array}{l}\text { TrkB } \\
\text { Postnatal } \\
3 \uparrow(\text { mRNA }) \\
2-(1 \text { mRNA, } 2 \text { protein })\end{array}$} \\
\hline & Postnatal & Prenatal & \\
\hline & $\begin{array}{l}6 \uparrow(4 \text { mRNA, } 2 \text { protein }) \\
4 \downarrow(3 \text { mRNA, } 2 \text { protein }) \\
2-(1 \text { mRNA, } 1 \text { protein })\end{array}$ & $\begin{array}{l}1 \uparrow \text { (protein) } \\
3 \downarrow(1 \text { mRNA, } 2 \text { protein })\end{array}$ & \\
\hline $\begin{array}{l}\text { Prefrontal } \\
\text { Cortex }\end{array}$ & $\begin{array}{l}4 \uparrow(3 \text { mRNA, } 2 \text { protein }) \\
2-(2 \text { mRNA, } 2 \text { protein })\end{array}$ & $\begin{array}{l}1 \uparrow \text { (protein) } \\
3 \downarrow(1 \text { mRNA, } 2 \text { protein })\end{array}$ & $\begin{array}{l}2 \uparrow(3 \mathrm{mRNA}, 1 \text { protein }) \\
3-(2 \mathrm{mRNA}, 3 \text { protein })\end{array}$ \\
\hline $\begin{array}{l}\text { Dorsal } \\
\text { Striatum }\end{array}$ & $2 \downarrow(1 \mathrm{mRNA}, 2$ protein $)$ & $\begin{array}{l}3 \uparrow(1 \text { mRNA, } 2 \text { protein }) \\
1 \downarrow \text { (mRNA \& protein })\end{array}$ & $1 \uparrow(\mathrm{mRNA})$ \\
\hline $\begin{array}{l}\text { Nucleus } \\
\text { Accumbens }\end{array}$ & $1 \uparrow($ protein) & $3 \uparrow(1 \mathrm{mRNA}, 2$ protein $)$ & $\begin{array}{l}1 \downarrow \text { (mRNA \& protein) } \\
1-(\text { mRNA \& protein })\end{array}$ \\
\hline
\end{tabular}

Values in brackets indicate the changes that occur at the mRNA or protein level. Where the total is greater than the summary value, this indicates a study would have looked at both mRNA and protein. 
Table 4: Summary of the effects of cigarette smoke and nicotine exposures on brain TrkB receptor expression in animal models

\begin{tabular}{|c|c|c|c|c|}
\hline Models & $\begin{array}{l}\text { Developmental } \\
\text { Stage when } \\
\text { brain studied }\end{array}$ & Method \& Brain region & Results & References \\
\hline \multicolumn{5}{|c|}{ Postnatal exposure } \\
\hline $\begin{array}{l}\text { Acute local } \\
\text { infusion straight } \\
\text { into } \\
\text { hippocampus }\end{array}$ & Adult male rat & $\begin{array}{l}\text { ISH; } \\
\text { Hippocampus }\end{array}$ & $\uparrow \mathrm{mRNA}$ & $\begin{array}{l}\text { French et al., } \\
1999\end{array}$ \\
\hline $\begin{array}{l}\text { Osmotic } \\
\mathrm{minipump} 3.15 \\
\mathrm{mg} / \mathrm{kg} / \text { day for } 7 \\
\text { days }\end{array}$ & Adult rat & $\begin{array}{l}\text { RT-PCR; WB; } \\
\text { PFC, Striatum, NAc, } \\
\text { Amygdala, medial basal } \\
\text { hypothalamus, } \\
\text { Hippocampus, VTA }\end{array}$ & $\begin{array}{l}\uparrow m R N A \text { in } \\
\text { PFC, } \\
\text { striatum, } \\
\downarrow \text { mRNA in } \\
\text { NAc \& VTA } \\
\uparrow \text { protein in } \\
\text { PFC, MBH, } \\
\downarrow \text { protein in } \\
\text { NAc \& VTA }\end{array}$ & Sun et al., 2007 \\
\hline $\begin{array}{l}\text { Chronic } \\
\text { exposure } \\
2 \mathrm{mg} / \mathrm{kg} / \text { day } \\
\text { nicotine osmotic } \\
\text { minipump for } 14 \\
\text { days }\end{array}$ & Infant piglet & IHC, brainstem & $\downarrow$ protein & Tang et al., 2008 \\
\hline $\begin{array}{l}\text { Osmotic } \\
\text { minipump } 1.2 \\
\mathrm{mg} \text { free } \\
\text { base/kg/d, for } 7 \\
\text { days. }\end{array}$ & $\begin{array}{l}\text { Age not } \\
\text { indicated; rat }\end{array}$ & $\begin{array}{l}\text { RT-PCR; WB; } \\
\text { Cerebral cortex, basal } \\
\text { forebrain }\end{array}$ & No change. & $\begin{array}{l}\text { Formaggio et al., } \\
2010\end{array}$ \\
\hline $\begin{array}{l}\text { Inhalation for } 10 \\
\text { days during } \\
\text { Infancy (P2-11) } \\
\text { and teenage } \\
\text { (P21-30) }\end{array}$ & Adult (P60)- mice & $\begin{array}{l}\text { RT-PCR \& WB; } \\
\text { hippocampus \& } \\
\text { prefrontal cortex }\end{array}$ & $\begin{array}{l}\text { Exposure in } \\
\text { infancy- } \\
\text { 个mRNA } \\
\text { hippocampus } \\
\text { only; } \\
\text { Teen- no } \\
\text { change }\end{array}$ & Xiao et al., 2016 \\
\hline \multicolumn{5}{|l|}{ Prenatal exposure } \\
\hline $\begin{array}{l}\text { Inhalation GD10 } \\
\text { for } 10 \text { days }\end{array}$ & Adult (P60)- mice & $\begin{array}{l}\text { RT-PCR \& WB; } \\
\text { hippocampus \& } \\
\text { prefrontal cortex }\end{array}$ & $\begin{array}{l}\uparrow \mathrm{mRNA} \text { both } \\
\text { brain regions }\end{array}$ & Xiao et al., 2016 \\
\hline
\end{tabular}




\section{References}

Alcantara, S., Frisen, J., del Rio, J.A., Soriano, E., Barbacid, M., Silos-Santiago, I., 1997. TrkB signaling is required for postnatal survival of CNS neurons and protects hippocampal and motor neurons from axotomy-induced cell death. Journal of Neuroscience. 17, 3623-33.

Aleisa, A.M., Alzoubi, K.H., Alkadhi, K.A., 2006. Nicotine prevents stress-induced enhancement of long-term depression in hippocampal area CA1: electrophysiological and molecular studies. Journal of Neuroscience Research. 83, 309-17.

Al-Sawalha, N.A., Migdadi, A.M., Alzoubi, K.H., Khabour, O.F., Qinna, N.A., 2017. Effect of waterpipe tobacco smoking on airway inflammation in murine model of asthma. Inhal Toxicol. 29, 46-52.

Autry, A.E., Monteggia, L.M., 2012. Brain-derived neurotrophic factor and neuropsychiatric disorders. Pharmacol Rev. 64, 238-58.

Baker, S.A., Stanford, L.E., Brown, R.E., Hagg, T., 2005. Maturation but not survival of dopaminergic nigrostriatal neurons is affected in developing and aging BDNF-deficient mice. Brain Research. 1039, 177-88.

Balkowiec, A., Katz, D.M., 1998. Brain-derived neurotrophic factor is required for normal development of the central respiratory rhythm in mice. J Physiol (Lond). 510, 527-33.

Balkowiec, A., Katz, D.M., 2002. Cellular mechanisms regulating activity-dependent release of native brain-derived neurotrophic factor from hippocampal neurons. J Neurosci. 22, 10399407.

Benowitz, N.L., Jacob, P., 3rd, 1993. Nicotine and cotinine elimination pharmacokinetics in smokers and nonsmokers. Clin Pharmacol Ther. 53, 316-23.

Benowitz, N.L., 1996. Pharmacology of nicotine: addiction and therapeutics. Annu Rev Pharmacol Toxicol. 36, 597-613.

Bernd, P., 2008. The role of neurotrophins during early development. Gene Expr. 14, 241-50.

Beuten, J., Ma, J.Z., Payne, T.J., Dupont, R.T., Quezada, P., Huang, W., Crews, K.M., Li, M.D., 2005. Significant association of BDNF haplotypes in European-American male smokers but not in European-American female or African-American smokers. Am J Med Genet B Neuropsychiatr Genet. 139B, 73-80.

Beuten, J., Ma, J.Z., Payne, T.J., Dupont, R.T., Lou, X.Y., Crews, K.M., Elston, R.C., Li, M.D., 2007. Association of specific haplotypes of neurotrophic tyrosine kinase receptor 2 gene (NTRK2) with vulnerability to nicotine dependence in African-Americans and EuropeanAmericans. Biol Psychiatry. 61, 48-55.

Bhang, S.Y., Choi, S.W., Ahn, J.H., 2010. Changes in plasma brain-derived neurotrophic factor levels in smokers after smoking cessation. Neurosci Lett. 468, 7-11.

Bianchi, L.M., Conover, J.C., Fritzsch, B., DeChiara, T., Lindsay, R.M., Yancopoulos, G.D., 1996. Degeneration of vestibular neurons in late embryogenesis of both heterozygous and homozygous BDNF null mutant mice. Development. 122, 1965-73.

Bramer, S.L., Kallungal, B.A., 2003. Clinical considerations in study designs that use cotinine as a biomarker. Biomarkers. 8, 187-203.

Browne, C.J., Sharma, N., Waters, K.A., Machaalani, R., 2010. The effects of nicotine on the alpha7 and beta-2 nicotinic acetycholine receptor subunits in the developing piglet brainstem. Int J Dev Neurosci. 28, 1-7.

Buisson, B., Bertrand, D., 2001. Chronic exposure to nicotine upregulates the human (alpha)4((beta)2 nicotinic acetylcholine receptor function. J Neurosci. 21, 1819-29.

Changeux, J.P., 2012. The nicotinic acetylcholine receptor: the founding father of the pentameric ligand-gated ion channel superfamily. Journal of Biological Chemistry. 287, 40207-15.

Chao, M.V., 2003. Neurotrophins and their receptors: a convergence point for many signalling pathways. Nat Rev Neurosci. 4, 299-309.

Chase, K.A., Sharma, R.P., 2013. Nicotine induces chromatin remodelling through decreases in the methyltransferases GLP, G9a, Setdb1 and levels of H3K9me2. Int J Neuropsychopharmcol. $16,1129-38$. 
Cohen, A., George, O., 2013. Animal models of nicotine exposure: relevance to second-hand smoking, electronic cigarette use, and compulsive smoking. Front Psychiatry. 4, 41.

Cohen-Cory, S., 2002. The developing synapse: construction and modulation of synaptic structures and circuits. Science. 298, 770-6.

Conover, J.C., Erickson, J.T., Katz, D.M., Bianchi, L.M., Poueymirou, W.T., McClain, J., Pan, L., Helgren, M., Ip, N.Y., Boland, P., et al., 1995. Neuronal deficits, not involving motor neurons, in mice lacking BDNF and/or NT4. Nature. 375, 235-8.

Cooper, E., Couturier, S., Ballivet, M., 1991. Pentameric structure and subunit stoichiometry of a neuronal nicotinic acetylcholine receptor. Nature. 350, 235-8.

Cunha, C., Brambilla, R., Thomas, K.L., 2010. A simple role for BDNF in learning and memory? Frontiers in molecular neuroscience. 3.

Czubak, A., Nowakowska, E., Kus, K., Burda, K., Metelska, J., Baer-Dubowska, W., Cichocki, M., 2009. Influences of chronic venlafaxine, olanzapine and nicotine on the hippocampal and cortical concentrations of brain-derived neurotrophic factor (BDNF). Pharmacol Rep. 61, 1017-23.

Damborsky, J.C., Winzer-Serhan, U.H., 2012. Effects of sex and chronic neonatal nicotine treatment on NKCC1, KCC2, BDNF, NR2A and NR2B mRNA expression in the postnatal rat hippocampus. Neuroscience. 225, 105-117.

Dani, J.A., Heinemann, S., 1996. Molecular and cellular aspects of nicotine abuse. Neuron. 16, 9058.

Edwards, R.H., Selby, M.J., Garcia, P.D., Rutter, W.J., 1988. Processing of the native nerve growth factor precursor to form biologically active nerve growth factor. J Biol Chem. 263, 6810-5.

Erickson, J.T., Conover, J.C., Borday, V., Champagnat, J., Barbacid, M., Yancopoulos, G., Katz, D.M., 1996. Mice lacking brain-derived neurotrophic factor exhibit visceral sensory neuron losses distinct from mice lacking NT4 and display a severe developmental deficit in control of breathing. The Journal of Neuroscience. 16, 5361-71.

Ernfors, P., Lee, K.F., Jaenisch, R., 1994. Mice lacking brain-derived neurotrophic factor develop with sensory deficits. Nature. 368, 147-50.

Ernfors, P., Bramham, C.R., 2003. The coupling of a trkB tyrosine residue to LTP. Trends Neurosci. 26, 171-3.

Fanous, A.M., Machaalani, R., Waters, K.A., 2006. N-methyl-D-aspartate receptor 1 changes in the piglet braintem after nicotine and/or intermittent hypercapnic-hypoxia. Neuroscience. 142, 401-9.

Fayard, B., Loeffler, S., Weis, J., Vogelin, E., Kruttgen, A., 2005. The secreted brain-derived neurotrophic factor precursor pro-BDNF binds to TrkB and p75NTR but not to TrkA or TrkC. J Neurosci Res. 80, 18-28.

Feduccia, A.A., Chatterjee, S., Bartlett, S.E., 2012. Neuronal nicotinic acetylcholine receptors: neuroplastic changes underlying alcohol and nicotine addictions. Frontiers in molecular neuroscience. 5, Article 83.

Feng, Y., Niu, T., Xing, H., Xu, X., Chen, C., Peng, S., Wang, L., Laird, N., 2004. A common haplotype of the nicotine acetylcholine receptor alpha 4 subunit gene is associated with vulnerability to nicotine addiction in men. Am J Hum Genet. 75, 112-21.

Filion, K.B., Abenhaim, H.A., Mottillo, S., Joseph, L., Gervais, A., O'Loughlin, J., Paradis, G., Pihl, R., Pilote, L., Rinfret, S., Tremblay, M., Eisenberg, M.J., 2011. The effect of smoking cessation counselling in pregnant women: a meta-analysis of randomised controlled trials. BJOG. 118, 1422-8.

Formaggio, E., Fazzini, F., Dalfini, A.C., Di Chio, M., Cantu, C., Decimo, I., Fiorini, Z., Fumagalli, G., Chiamulera, C., 2010. Nicotine increases the expression of neurotrophin receptor tyrosine kinase receptor A in basal forebrain cholinergic neurons. Neuroscience. 166, 580-9.

Freedman, R., Wetmore, C., Stromberg, I., Leonard, S., Olson, L., 1993. Alpha-bungarotoxin binding to hippocampal interneurons: immunocytochemical characterization and effects on growth factor expression. Journal of Neuroscience. 13, 1965-75. 
Freedman, R., Adams, C.E., Leonard, S., 2000. The alpha7-nicotinic acetylcholine receptor and the pathology of hippocampal interneurons in schizophrenia. J Chem Neuroanat. 20, 299-306.

French, S.J., Humby, T., Horner, C.H., Sofroniew, M.V., Rattray, M., 1999. Hippocampal neurotrophin and trk receptor mRNA levels are altered by local administration of nicotine, carbachol and pilocarpine. Brain Res Mol Brain Res. 67, 124-36.

Frisen, J., Verge, V.M., Fried, K., Risling, M., Persson, H., Trotter, J., Hokfelt, T., Lindholm, D., 1993. Characterization of glial trkB receptors: differential response to injury in the central and peripheral nervous systems. Proc Natl Acad Sci U S A. 90, 4971-5.

Fujimura, H., Altar, C.A., Chen, R., Nakamura, T., Nakahashi, T., Kambayashi, J., Sun, B., Tandon, N.N., 2002. Brain-derived neurotrophic factor is stored in human platelets and released by agonist stimulation. Thromb Haemost. 87, 728-34.

Fukuchi, M., Izumi, H., Mori, H., Kiyama, M., Otsuka, S., Maki, S., Maehata, Y., Tabuchi, A., Tsuda, M., 2017. Visualizing changes in brain-derived neurotrophic factor (BDNF) expression using bioluminescence imaging in living mice. Scientific reports. 7, 4949.

Gotti, C., Fornasari, D., Clementi, F., 1997. Human neuronal nicotinic receptors. Prog Neurobiol. 53, 199-237.

Gotti, C., Clementi, F., 2004. Neuronal nicotinic receptors: from structure to pathology. Progress in Neurobiology. 74, 363-96.

Gupta, V.K., You, Y., Gupta, V.B., Klistorner, A., Graham, S.L., 2013. TrkB receptor signalling: implications in neurodegenerative, psychiatric and proliferative disorders. Int. j. mol. sci. 14, 10122-42.

Hafidi, A., 1999. Distribution of BDNF, NT-3 and NT-4 in the developing auditory brainstem. Int J Dev Neurosci. 17, 285-94.

Harrist, A., Beech, R.D., King, S.L., Zanardi, A., Cleary, M.A., Caldarone, B.J., Eisch, A., Zoli, M., Picciotto, M.R., 2004. Alteration of hippocampal cell proliferation in mice lacking the beta 2 subunit of the neuronal nicotinic acetylcholine receptor. Synapse. 54, 200-6.

Harrod, S.B., Lacy, R.T., Zhu, J., Hughes, B.A., Perna, M.K., Brown, R.W., 2011. Gestational IV nicotine produces elevated brain-derived neurotrophic factor in the mesocorticolimbic dopamine system of adolescent rat offspring. Synapse. 65, 1382-92.

Holm, P.C., Rodriguez, F.J., Kresse, A., Canals, J.M., Silos-Santiago, I., Arenas, E., 2003. Crucial role of TrkB ligands in the survival and phenotypic differentiation of developing locus coeruleus noradrenergic neurons. Development. 130, 3535-45.

Hunt, C.E., 1992. The cardiorespiratory control hypothesis for sudden infant death syndrome. Clin Perinatol. 19, 757-71.

Hutchison, K.E., Allen, D.L., Filbey, F.M., Jepson, C., Lerman, C., Benowitz, N.L., Stitzel, J., Bryan, A., McGeary, J., Haughey, H.M., 2007. CHRNA4 and tobacco dependence: from gene regulation to treatment outcome. Arch Gen Psychiatry. 64, 1078-86.

Iritani, S., Niizato, K., Nawa, H., Ikeda, K., Emson, P.C., 2003. Immunohistochemical study of brain-derived neurotrophic factor and its receptor, $\operatorname{TrkB}$, in the hippocampal formation of schizophrenic brains. Prog Neuropsychopharmacol Biol Psychiatry. 27, 801-7.

Jamal, M., Van der Does, W., Elzinga, B.M., Molendijk, M.L., Penninx, B.W., 2015. Association between smoking, nicotine dependence, and BDNF Val66Met polymorphism with BDNF concentrations in serum. Nicotine Tob Res. 17, 323-9.

Jones, K.R., Farinas, I., Backus, C., Reichardt, L.F., 1994. Targeted disruption of the BDNF gene perturbs brain and sensory neuron development but not motor neuron development. Cell. 76, 989-99.

Karege, F.1., Schwald, M.1., Cisse, M., 2002. Postnatal developmental profile of brain-derived neurotrophic factor in rat brain and platelets. Neurosci Lett. 328, 261-264.

Kawamoto, Y., Nakamura, S., Nakano, S., Oka, N., Akiguchi, I., Kimura, J., 1996. Immunohistochemical localization of brain-derived neurotrophic factor in adult rat brain. Neuroscience. 74, 1209-26. 
Kawamoto, Y., Nakamura, S., Kawamata, T., Akiguchi, I., Kimura, J., 1999. Cellular localization of brain-derived neurotrophic factor-like immunoreactivity in adult monkey brain. Brain Res. 821, 341-9.

Kendler, K.S., Sundquist, K., Ohlsson, H., Palmer, K., Maes, H., Winkleby, M.A., Sundquist, J., 2012. Genetic and familial environmental influences on the risk for drug abuse: a national Swedish adoption study. Arch Gen Psychiatry. 69, 690-7.

Kenny, P.J., File, S.E., Rattray, M., 2000. Acute nicotine decreases, and chronic nicotine increases the expression of brain-derived neurotrophic factor mRNA in rat hippocampus. Brain Res Mol Brain Res. 85, 234-8.

Kim, Y.K., Lee, H.P., Won, S.D., Park, E.Y., Lee, H.Y., Lee, B.H., Lee, S.W., Yoon, D., Han, C., Kim, D.J., Choi, S.H., 2007. Low plasma BDNF is associated with suicidal behavior in major depression. Prog Neuropsychopharmacol Biol Psychiatry. 31, 78-85.

Kivinummi, T., Kaste, K., Rantamaki, T., Castren, E., Ahtee, L., 2011. Alterations in BDNF and phospho-CREB levels following chronic oral nicotine treatment and its withdrawal in dopaminergic brain areas of mice. Neurosci Lett. 491, 108-12.

Klein, R., Smeyne, R.J., Wurst, W., Long, L.K., Auerbach, B.A., Joyner, A.L., Barbacid, M., 1993. Targeted disruption of the trkB neurotrophin receptor gene results in nervous system lesions and neonatal death. Cell. 75, 113-22.

Klein, A.B., Williamson, R., Santini, M.A., Clemmensen, C., Ettrup, A., Rios, M., Knudsen, G.M., Aznar, S., 2011. Blood BDNF concentrations reflect brain-tissue BDNF levels across species. Int J Neuropsychopharmcol. 14, 347-53.

Korte, M., Staiger, V., Griesbeck, O., Thoenen, H., Bonhoeffer, T., 1996. The involvement of brain-derived neurotrophic factor in hippocampal long-term potentiation revealed by gene targeting experiments. J Physiol Paris. 90, 157-64.

Lacy, R.T., Brown, R.W., Morgan, A.J., Mactutus, C.F., Harrod, S.B., 2016. Intravenous Prenatal Nicotine Exposure Alters METH-Induced Hyperactivity, Conditioned Hyperactivity, and BDNF in Adult Rat Offspring. Dev Neurosci. 38, 171-185.

Lang, U.E., Sander, T., Lohoff, F.W., Hellweg, R., Bajbouj, M., Winterer, G., Gallinat, J., 2007. Association of the met66 allele of brain-derived neurotrophic factor (BDNF) with smoking. Psychopharmacology. 190, 433-9.

Lavezzi, A.M., Corna, M.F., Matturri, L., 2014. Disruption of the brain-derived neurotrophic factor (BDNF) immunoreactivity in the human Kolliker-Fuse nucleus in victims of unexplained fetal and infant death. Frontiers in human neuroscience. 8.

Lavezzi, A.M., Ferrero, S., Lattuada, D., Piscioli, F., Alfonsi, G., Matturri, L., 2018.

Pathobiological expression of the brain-derived neurotrophic factor (BDNF) in cerebellar cortex of sudden fetal and infant death victims. International Journal of Developmental Neuroscience. 66, 9-17.

Li, M.D., Beuten, J., Ma, J.Z., Payne, T.J., Lou, X.Y., Garcia, V., Duenes, A.S., Crews, K.M., Elston, R.C., 2005. Ethnic- and gender-specific association of the nicotinic acetylcholine receptor alpha4 subunit gene (CHRNA4) with nicotine dependence. Hum Mol Genet. 14, 1211-9.

Li, M.D., Lou, X.Y., Chen, G., Ma, J.Z., Elston, R.C., 2008. Gene-gene interactions among CHRNA4, CHRNB2, BDNF, and NTRK2 in nicotine dependence. Biol Psychiatry. 64, 9517.

Lichtensteiger, W., Ribary, U., Schlumpf, M., Odermatt, B., Widmer, H.R., 1988. Prenatal adverse effects of nicotine on the developing brain. Prog Brain Res. 73, 137-57.

Lindstrom, J., 1997. Nicotinic acetylcholine receptors in health and disease. Mol Neurobiol. 15, 193-222.

Lommatzsch, M., Zingler, D., Schuhbaeck, K., Schloetcke, K., Zingler, C., Schuff-Werner, P., Virchow, J.C., 2005. The impact of age, weight and gender on BDNF levels in human platelets and plasma. Neurobiol Aging. 26, 115-23. 
Lotfipour, S., Ferguson, E., Leonard, G., Perron, M., Pike, B., Richer, L., Seguin, J.R., Toro, R., Veillette, S., Pausova, Z., Paus, T., 2009. Orbitofrontal cortex and drug use during adolescence: role of prenatal exposure to maternal smoking and BDNF genotype. Arch Gen Psychiatry. 66, 1244-52.

Lotto, R.B., Asavaritikrai, P., Vali, L., Price, D.J., 2001. Target-derived neurotrophic factors regulate the death of developing forebrain neurons after a change in their trophic requirements. Journal of Neuroscience. 21, 3904-10.

Luck, W., Nau, H., 1985. Nicotine and cotinine concentrations in serum and urine of infants exposed via passive smoking or milk from smoking mothers. J Pediatr. 107, 816-20.

Lueders, K.K., Hu, S., McHugh, L., Myakishev, M.V., Sirota, L.A., Hamer, D.H., 2002. Genetic and functional analysis of single nucleotide polymorphisms in the beta2-neuronal nicotinic acetylcholine receptor gene (CHRNB2). Nicotine Tob Res. 4, 115-25.

Luikart, B.W., Nef, S., Virmani, T., Lush, M.E., Liu, Y., Kavalali, E.T., Parada, L.F., 2005. TrkB has a cell-autonomous role in the establishment of hippocampal Schaffer collateral synapses. J Neurosci. 25, 3774-86.

Luo, X.G., Rush, R.A., Zhou, X.F., 2001. Ultrastructural localization of brain-derived neurotrophic factor in rat primary sensory neurons. Neurosci Res. 39, 377-84.

Machaalani, R., Waters, K.A., Tinworth, K.D., 2005. Effects of postnatal nicotine exposure on apoptotic markers in the developing piglet brain. Neuroscience. 132, 325-33.

Machaalani, R., Hunt N, Waters KA., 2016. Brain orexin receptors and nicotine. In Neuropathology of Drug Addictions and Substance Misuse Volume 1: Foundations of Understanding, Tobacco, Alcohol, Cannabinoids and Opioids. Editor: Preedy, Victor R., Vol., Academic Press.

Markou, A., 2008. Neurobiology of nicotine dependence. Philosophical Transactions of the Royal Society B: Biological Sciences. 363, 3159-3168.

Massey, K.A., Zago, W.M., Berg, D.K., 2006. BDNF up-regulates alpha7 nicotinic acetylcholine receptor levels on subpopulations of hippocampal interneurons. Mol Cell Neurosci. 33, 3818.

Mitchell, E.A., Freemantle, J., Young, J., Byard, R.W., 2012. Scientific consensus forum to review the evidence underpinning the recommendations of the Australian SIDS and Kids Safe Sleeping Health Promotion Programmeâ€"October 2010. Journal of paediatrics and child health. 48, 626-633.

Monteggia, L.M., Arneric, S.P., Giordano, T., 1994. Nicotine effects on the regulation of amyloid precursor protein splicing, neurotrophin and glucose transporter RNA levels in aged rats. International Journal of Developmental Neuroscience. 12, 133-41.

Mowla, S.J., Farhadi, H.F., Pareek, S., Atwal, J.K., Morris, S.J., Seidah, N.G., Murphy, R.A., 2001. Biosynthesis and post-translational processing of the precursor to brain-derived neurotrophic factor. J Biol Chem. 276, 12660-6.

Murer, M.G., Boissiere, F., Yan, Q., Hunot, S., Villares, J., Faucheux, B., Agid, Y., Hirsch, E., Raisman-Vozari, R., 1999. An immunohistochemical study of the distribution of brainderived neurotrophic factor in the adult human brain, with particular reference to Alzheimer's disease. Neuroscience. 88, 1015-32.

Murer, M.G., Yan, Q., Raisman-Vozari, R., 2001. Brain-derived neurotrophic factor in the control human brain, and in Alzheimer's disease and Parkinson's disease. Progress in Neurobiology. 63, 71-124.

Murrin, L.C., Ferrer, J.R., Zeng, W.Y., Haley, N.J., 1987. Nicotine administration to rats: methodological considerations. Life Sci. 40, 1699-708.

Naha, N., Gandhi, D.N., Gautam, A.K., Prakash, J.R., 2017. Nicotine and cigarette smoke modulate Nrf2-BDNF-dopaminergic signal and neurobehavioral disorders in adult rat cerebral cortex\#. Human \& experimental toxicology. 0960327117698543. 
Neves, C.D.C., Lacerda, A.C.R., Lima, L.P., Lage, V.K.S., Balthazar, C.H., Leite, H.R., MendonÃ §a, V.A., 2017. Different levels of brain-derived neurotrophic factor and cortisol in healthy heavy smokers. Brazilian Journal of Medical and Biological Research. 50.

Obrietan, K., Gao, X.B., Van Den Pol, A.N., 2002. Excitatory actions of GABA increase BDNF expression via a MAPK-CREB-dependent mechanism--a positive feedback circuit in developing neurons. J Neurophysiol. 88, 1005-15.

Ortega, L.A., Tracy, B.A., Gould, T.J., Parikh, V., 2013. Effects of chronic low- and high-dose nicotine on cognitive flexibility in C57BL/6J mice. Behav Brain Res. 238, 134-45.

Pan, W., Banks, W.A., Fasold, M.B., Bluth, J. and Kastin, A.J., 1998. Transport of brain-derived neurotrophic factor across the blood-brain barrier. Neuropharmacology, 37(12),1553-1561.

Pang, P.T., Teng, H.K., Zaitsev, E., Woo, N.T., Sakata, K., Zhen, S., Teng, K.K., Yung, W.H., Hempstead, B.L., Lu, B., 2004. Cleavage of proBDNF by tPA/plasmin is essential for longterm hippocampal plasticity. Science. 306, 487-91.

Papke, R.L., Dwoskin, L.P., Crooks, P.A., Zheng, G., Zhang, Z., McIntosh, J.M., Stokes, C., 2008. Extending the analysis of nicotinic receptor antagonists with the study of alpha6 nicotinic receptor subunit chimeras. Neuropharmacology. 54, 1189-200.

Patapoutian, A., Reichardt, L.F., 2001. Trk receptors: mediators of neurotrophin action. Curr Opin Neurobiol. 11, 272-80.

Patel, A.V., Krimm, R.F., 2010. BDNF is required for the survival of differentiated geniculate ganglion neurons. Dev Biol. 340, 419-29.

Patterson, S.L., Abel, T., Deuel, T.A., Martin, K.C., Rose, J.C., Kandel, E.R., 1996. Recombinant BDNF rescues deficits in basal synaptic transmission and hippocampal LTP in BDNF knockout mice. Neuron. 16, 1137-45.

Peiris, T.S., Machaalani, R., Waters, K.A., 2004. Brain-derived neurotrophic factor mRNA and protein in the piglet brainstem and effects of Intermittent Hypercapnic Hypoxia. Brain Res. $1029,11-23$.

Piccinni, A., Marazziti, D., Del Debbio, A., Bianchi, C., Roncaglia, I., Mannari, C., Origlia, N., Catena Dell'Osso, M., Massimetti, G., Domenici, L., Dell'Osso, L., 2008. Diurnal variation of plasma brain-derived neurotrophic factor (BDNF) in humans: an analysis of sex differences. Chronobiol Int. 25, 819-26.

Poon, K., Leibowitz, S.F., 2016. Consumption of Substances of Abuse during Pregnancy Increases Consumption in Offspring: Possible Underlying Mechanisms. Frontiers in nutrition. 3.

Radka, S.F., Holst, P.A., Fritsche, M., Altar, C.A., 1996. Presence of brain-derived neurotrophic factor in brain and human and rat but not mouse serum detected by a sensitive and specific immunoassay. Brain Research. 709, 122-301.

Role, L.W., Berg, D.K., 1996. Nicotinic receptors in the development and modulation of CNS synapses. Neuron. 16, 1077-85.

Romano, E., De Angelis, F., Ulbrich, L., De Jaco, A., Fuso, A., Laviola, G., 2014. Nicotine exposure during adolescence: cognitive performance and brain gene expression in adult heterozygous reeler mice. Psychopharmacology. 231, 1775-87.

Rose, C.R., Blum, R., Kafitz, K.W., Kovalchuk, Y., Konnerth, A., 2004. From modulator to mediator: rapid effects of BDNF on ion channels. Bioessays. 26, 1185-94.

Rosenfeld, R.D., Zeni, L., Haniu, N., Talvenheimo, J., Radka, S.F., Bennett, L., Miller, J.A., Welcher, A.A., 1995. Purification and identification of brain-derived neurotrophic factor from human serum. Protein expression and purification. 6, 465-471.

Say, M., Machaalani, R., Waters, K.A., 2007. Changes in serotoninergic receptors 1A and 2A in the piglet brainstem after intermittent hypercapnic hypoxia (IHH) and nicotine. Brain Res. $1152,17-26$.

Schlessinger, J., Ullrich, A., 1992. Growth factor signaling by receptor tyrosine kinases. Neuron. 9, 383-91. 
Schwartz, P.M., Borghesani, P.R., Levy, R.L., Pomeroy, S.L., Segal, R.A., 1997. Abnormal cerebellar development and foliation in BDNF-/- mice reveals a role for neurotrophins in CNS patterning. Neuron. 19, 269-81.

Seidah, N.G., Benjannet, S., Pareek, S., Chretien, M., Murphy, R.A., 1996. Cellular processing of the neurotrophin precursors of NT3 and BDNF by the mammalian proprotein convertases. FEBS Lett. 379, 247-50.

Silverman, M.A., Neale, M.C., Sullivan, P.F., Harris-Kerr, C., Wormley, B., Sadek, H., Ma, Y., Kendler, K.S., Straub, R.E., 2000. Haplotypes of four novel single nucleotide polymorphisms in the nicotinic acetylcholine receptor beta2-subunit (CHRNB2) gene show no association with smoking initiation or nicotine dependence. Am J Med Genet. 96, 64653.

Slotkin, T.A., 1998. Fetal nicotine or cocaine exposure: which one is worse? J Pharmacol Exp Ther. 285, 931-45.

Son, J.H., Winzer-Serhan, U.H., 2009. Chronic neonatal nicotine exposure increases mRNA expression of neurotrophic factors in the postnatal rat hippocampus. Brain Research. 1278, $1-14$.

Sparks, J.A., Pauly, J.R., 1999. Effects of continuous oral nicotine administration on brain nicotinic receptors and responsiveness to nicotine in C57B1/6 mice. Psychopharmacology (Berl). 141, 145-53.

SSWPS Handbook 2014: http://www.swslhd.nsw.gov.au/sswps/handbook

Steinlein, O.K., 2000. Neuronal nicotinic receptors in human epilepsy. Eur J Pharmacol. 393, 2437.

Sun, D., Huang, W., Hwang, Y.Y., Zhang, Y., Zhang, Q., Li, M.D., 2007. Regulation by nicotine of Gpr51 and Ntrk2 expression in various rat brain regions. Neuropsychopharmacology. 32, $110-6$.

Suriyaprom, K., Tungtrongchitr, R., Thawnashom, K., Pimainog, Y., 2013. BDNF Val66Met polymorphism and serum concentrations of BDNF with smoking in Thai males. Genet Mol Res. 12, 4925-33.

Tang, S., Machaalani, R., Waters, K.A., 2008. Brain-derived neurotrophic factor (BDNF) and TrkB in the piglet brainstem after post-natal nicotine and intermittent hypercapnic hypoxia. Brain Res. 1232, 195-205.

Tang, S., Machaalani, R., Waters, K.A., 2010. Immunolocalization of pro- and mature-brain derived neurotrophic factor (BDNF) and receptor TrkB in the human brainstem and hippocampus. Brain Res. 1354, 1-14.

Tang, S., Machaalani, R., Waters, K.A., 2012. Expression of brain-derived neurotrophic factor and TrkB receptor in the sudden infant death syndrome brainstem. Respir Physiol Neurobiol. $180,25-33$

Tapia-Arancibia, L., Rage, F., Givalois, L., Arancibia, S., 2004. Physiology of BDNF: focus on hypothalamic function. Front Neuroendocrinol. 25, 77-107.

Teng, H.K., Teng, K.K., Lee, R., Wright, S., Tevar, S., Almeida, R.D., Kermani, P., Torkin, R., Chen, Z.Y., Lee, F.S., Kraemer, R.T., Nykjaer, A., Hempstead, B.L., 2005. ProBDNF induces neuronal apoptosis via activation of a receptor complex of p75NTR and sortilin. $\mathrm{J}$ Neurosci. 25, 5455-63.

Teyler, T.J. and DiScenna, P., 1987. Long-term potentiation. Annual review of neuroscience, 10(1), pp.131-161.

Tierney, T., Doubell, T., Xia, G., Moore, D., 2001. Development of brain-derived neurotrophic factor and neurotrophin-3 immunoreactivity in the lower auditory brainstem of the postnatal gerbil. European journal of neuroscience. 14, 785-793.

Toledo-Rodriguez, M., Lotfipour, S., Leonard, G., Perron, M., Richer, L., Veillette, S., Pausova, Z., Paus, T., 2010. Maternal smoking during pregnancy is associated with epigenetic modifications of the brain-derived neurotrophic factor- 6 exon in adolescent offspring. Am J Med Genet B Neuropsychiatr Genet. 153B, 1350-4. 
Tonra, J.R., 1999. Classical and novel directions in neurotrophin transport and research: anterograde transport of brain-derived neurotrophic factor by sensory neurons. Microsc Res Tech. 45, 225-32.

Torres, L.H., Garcia, R.C., Blois, A.M., Dati, L.M., Durao, A.C., Alves, A.S., Pacheco-Neto, M., Mauad, T., Britto, L.R., Xavier, G.F., Camarini, R., Marcourakis, T., 2015. Exposure of Neonatal Mice to Tobacco Smoke Disturbs Synaptic Proteins and Spatial Learning and Memory from Late Infancy to Early Adulthood. PLoS ONE. 10, e0136399.

Trauth, J.A., McCook, E.C., Seidler, F.J., Slotkin, T.A., 2000. Modeling adolescent nicotine exposure: effects on cholinergic systems in rat brain regions. Brain Res. 873, 18-25.

Tuon, T., Valvassori, S.S., Lopes-Borges, J., Fries, G.R., Silva, L.A., Kapczinski, F., Quevedo, J., Pinho, R.A., 2010. Effects of moderate exercise on cigarette smoke exposure-induced hippocampal oxidative stress values and neurological behaviors in mice. Neurosci Lett. 475, 16-9.

Ullal, G.R., Michalski, B., Xu, B., Racine, R.J., Fahnestock, M., 2007. NT-3 modulates BDNF and proBDNF levels in naive and kindled rat hippocampus. Neurochem Int. 50, 866-71.

Vine, M.F., Hulka, B.S., Margolin, B.H., Truong, Y.K., Hu, P.C., Schramm, M.M., Griffith, J.D., McCann, M., Everson, R.B., 1993. Cotinine concentrations in semen, urine, and blood of smokers and nonsmokers. Am J Public Health. 83, 1335-8.

Vivekanandarajah, A., Waters, K.A., Machaalani, R., 2015. Postnatal nicotine effects on the expression of nicotinic acetylcholine receptors in the developing piglet hippocampus and brainstem. Int J Dev Neurosci. 47, 183-91.

Vivekanandarajah, A., Chan, Y.L., Chen, H., Machaalani, R., 2016. Prenatal cigarette smoke exposure effects on apoptotic and nicotinic acetylcholine receptor expression in the infant mouse brainstem. Neurotoxicology. 53, 53-63.

Wang, H.Y., Lee, D.H., D'Andrea, M.R., Peterson, P.A., Shank, R.P., Reitz, A.B., 2000. betaAmyloid(1-42) binds to alpha7 nicotinic acetylcholine receptor with high affinity. Implications for Alzheimer's disease pathology. J Biol Chem. 275, 5626-32.

Webster, M.J., Weickert, C.S., Herman, M.M., Kleinman, J.E., 2002. BDNF mRNA expression during postnatal development, maturation and aging of the human prefrontal cortex. Brain Research. Developmental Brain Research. 139, 139-50.

Wei, J., Wang, J., Dwyer, J.B., Mangold, J., Cao, J., Leslie, F.M., Li, M.D., 2011. Gestational nicotine treatment modulates cell death/survival-related pathways in the brains of adolescent female rats. Int J Neuropsychopharmcol. 14, 91-106.

WHOa: World Health Organisation http://www.who.int/gho/tobacco/use/en/

WHOb: World Health Organisation http://www.who.int/mediacentre/factsheets/fs339/en/

Xiao, L., Kish, V.L., Benders, K.M., Wu, Z.-X., 2016. Prenatal and early postnatal exposure to cigarette smoke decreases BDNF/TrkB signaling and increases abnormal behaviors later in life. Int J Neuropsychopharmcol. 19, 1-11.

Xiaoyu, W., 2015. The exposure to nicotine affects expression of brain-derived neurotrophic factor (BDNF) and nerve growth factor (NGF) in neonate rats. Neurological Sciences. 36, 289295.

Yan, Q., Rosenfeld, R.D., Matheson, C.R., Hawkins, N., Lopez, O.T., Bennett, L., Welcher, A.A., 1997. Expression of brain-derived neurotrophic factor protein in the adult rat central nervous system. Neuroscience. 78, 431-48.

Yeom, M., Shim, I., Lee, H.J., Hahm, D.H., 2005. Proteomic analysis of nicotine-associated protein expression in the striatum of repeated nicotine-treated rats. Biochem Biophys Res Commun. $326,321-8$

Yochum, C., Doherty-Lyon, S., Hoffman, C., Hossain, M.M., Zelikoff, J.T., Richardson, J.R., 2014. Prenatal cigarette smoke exposure causes hyperactivity and aggressive behavior: role of altered catecholamines and BDNF. Experimental neurology. 254, 145-152. 
Zhang, H.T., Li, L.Y., Zou, X.L., Song, X.B., Hu, Y.L., Feng, Z.T., Wang, T.T., 2007. Immunohistochemical distribution of NGF, BDNF, NT-3, and NT-4 in adult rhesus monkey brains. J Histochem Cytochem. 55, 1-19.

Zhang, X.Y., Xiu, M.H., Chen, D.C., Yang, F.D., Wu, G.Y., Lu, L., Kosten, T.A., Kosten, T.R., 2010. Nicotine dependence and serum BDNF levels in male patients with schizophrenia. Psychopharmacology. 212, 301-7.

Zhang, X.Y., Chen, D.C., Xiu, M.H., Luo, X., Zuo, L., Haile, C.N., Kosten, T.A., Kosten, T.R., 2012. BDNF Val66Met variant and smoking in a Chinese population. PLoS ONE. 7, e53295.

Zhang, X.Y., Chen, D.C., Tan, Y.L., Luo, X., Zuo, L., Lv, M.H., Shah, N.N., Zunta-Soares, G.B., Soares, J.C., 2015. Smoking and BDNF Val66Met polymorphism in male schizophrenia: a case-control study. J Psychiatr Res. 60, 49-55.

Zhang, X.Y., Tan, Y.L., Chen, D.C., Tan, S.P., Yang, F.D., Zunta-Soares, G.B., Soares, J.C., 2016. Effects of cigarette smoking and alcohol use on neurocognition and BDNF levels in a Chinese population. Psychopharmacology. 233, 435-45.

Zhou, X.F., Rush, R.A., 1996. Endogenous brain-derived neurotrophic factor is anterogradely transported in primary sensory neurons. Neuroscience. 74, 945-53.

Zhou, X., Nai, Q., Chen, M., Dittus, J.D., Howard, M.J., Margiotta, J.F., 2004. Brain-derived neurotrophic factor and trkB signaling in parasympathetic neurons: relevance to regulating $\alpha 7$-containing nicotinic receptors and synaptic function. Journal of Neuroscience. 24, 43404350 . 


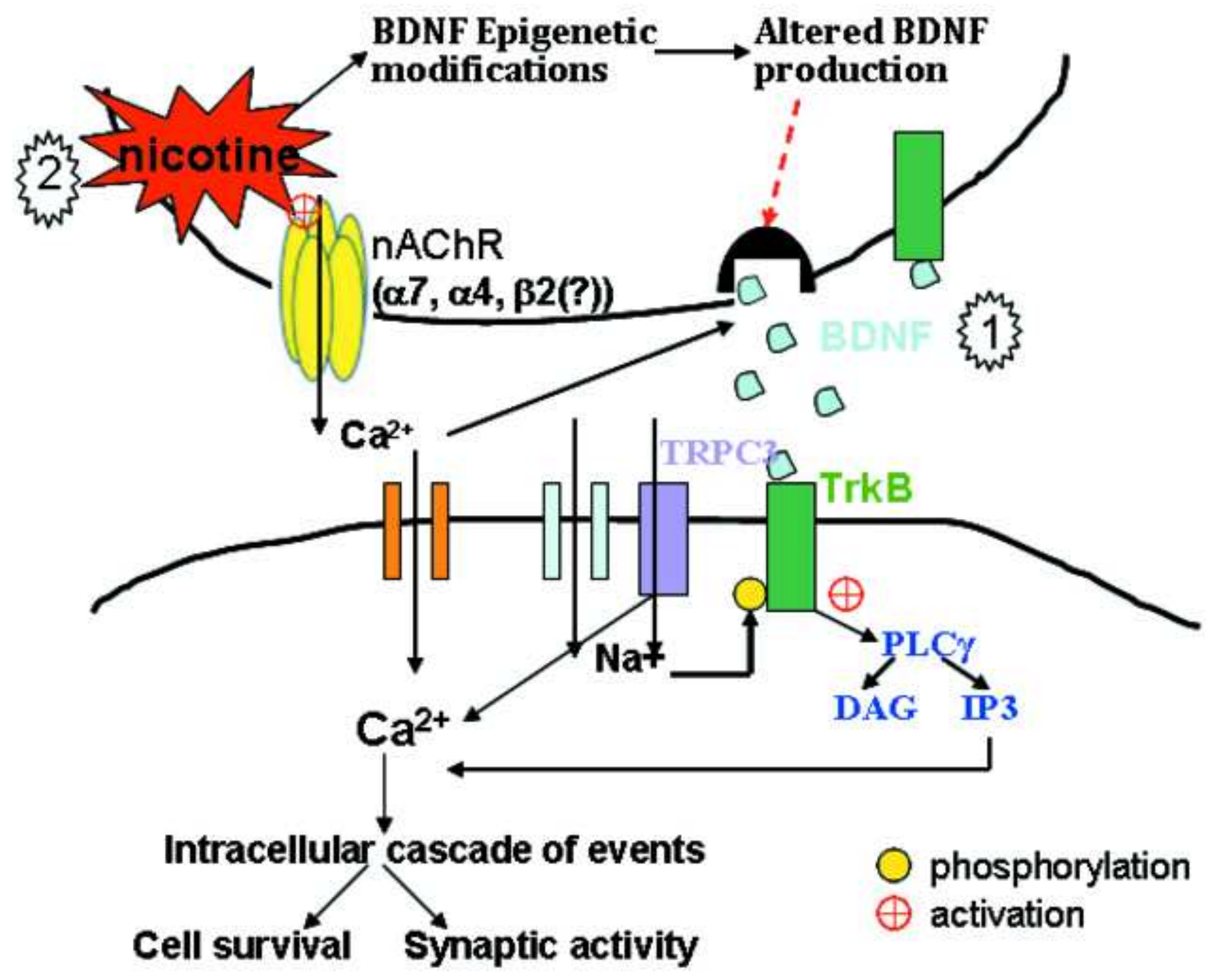

